\title{
Evaluating the Effect of Feed Mixing and Sampling Methodologies on Nutrient Analysis and the Inclusion of a Novel Protease in Broiler Diets
}

Danielle A. Reese

Follow this and additional works at: https://researchrepository.wvu.edu/etd

\section{Recommended Citation}

Reese, Danielle A., "Evaluating the Effect of Feed Mixing and Sampling Methodologies on Nutrient Analysis and the Inclusion of a Novel Protease in Broiler Diets" (2016). Graduate Theses, Dissertations, and Problem Reports. 6491.

https://researchrepository.wvu.edu/etd/6491

This Thesis is protected by copyright and/or related rights. It has been brought to you by the The Research Repository @ WVU with permission from the rights-holder(s). You are free to use this Thesis in any way that is permitted by the copyright and related rights legislation that applies to your use. For other uses you must obtain permission from the rights-holder(s) directly, unless additional rights are indicated by a Creative Commons license in the record and/ or on the work itself. This Thesis has been accepted for inclusion in WVU Graduate Theses, Dissertations, and Problem Reports collection by an authorized administrator of The Research Repository @ WVU. For more information, please contact researchrepository@mail.wvu.edu. 
Evaluating the Effect of Feed Mixing and Sampling Methodologies on Nutrient Analysis and the Inclusion of a Novel Protease in Broiler Diets.

\author{
Danielle A. Reese
}

Thesis submitted

to the Davis College of Agriculture, Natural Resources, and Design

at West Virginia University

in partial fulfillment of the requirements for the degree of

\author{
Master of Science \\ In \\ Nutritional and Food Science \\ Joseph S. Moritz, Ph.D, Chair \\ Jacek Jaczynski, Ph.D \\ Eugene Felton, Ph.D \\ Division of Animal and Nutritional Sciences
}

Morgantown, West Virginia
2016

Keywords: Mixing, Sampling, Broiler, Protease, Assay

Copyright 2016 Danielle A. Reese 


\section{ABSTRACT \\ Evaluating the Effect of Feed Mixing and Sampling Variables on Nutrient Analysis and the Inclusion of an Novel Protease}

\section{Danielle A. Reese}

Proper poultry feeding requires a homogenous mixture of macro and micro ingredients to ensure feed nutrients are being supplied to meet bird requirements. Samples of complete feed may be taken during manufacture and analyzed for nutrient content in order to estimate if nutrients are present in feed in accordance to diet formulation. However, variables associated with mixing and feed sampling may influence the results of nutrient analysis, thus over or under estimating the formula comparison. The objective of this study was to vary mix time, sample location, sample number, and sample blending technique on nutrient analysis. Ingredients were mixed in a single screw vertical mixer for either 30 seconds or 10 minutes. Samples were taken from either the pellet die or from the finished feed post cooling, conveyance, and bagging. Samples were blended together from two or 10 samples during manufacture. Blending occurred from either combining samples and mixing by hand or using a sample splitting device. Proximate analysis and free supplemental DL-methionine and L-lysine-HCl were determined on each blended sample and standardized for moisture content. A preliminary study was performed to determine mixer coefficient of variation and showed that ingredients were homogenous when a corn-salt mix was utilized and mixed for 10 minutes $(\mathrm{P}<0.05)$. In the primary study, crude fat and free supplemental DL-methionine were affected by mix time $(\mathrm{P}<0.05)$. The 10 minute mix time produced values for crude fat and free supplemental DL-methionine that were lower and higher, respectively, compared to the $30 \mathrm{sec}$ mix time and agreed more with the calculated nutrient profile and diet formulation. Free supplemental DL-methionine was also affected by sampling location $(\mathrm{P}<0.05)$. Samples obtained at the pellet die were higher and agreed more with the calculated nutrient profile compared to finished feed samples obtained at the sack off bin. Total ash was affected by a sampling location and sampling technique interaction $(\mathrm{P}<0.05)$. Samples collected at the pellet die were in closer agreement regardless of sample number; whereas, finished feed samples obtained at the sack off bin were affected more by sample number. These data suggest that mixing and sampling variables can effect nutrient analysis and sampling protocols should be utilized to best estimate if nutrients present in feed are in agreement with diet formulation. The particular conditions of the study suggest that analysis of free supplemental DL-methionine from samples obtained at the pellet die may be the best metric for determining pelleted diet homogeneity and accordance relative to diet formulation.

Exogenous enzymes added at the mixer should demonstrate activity post-pelleting and improve bird performance to justify use in the broiler industry. Past research has shown that diet substrate and the pelleting process can effect enzyme efficacy. The objective of the study was to evaluate the feeding value of a novel protease in unprocessed mash and pelleted diets that were composed of all vegetable protein or an inclusion of animal protein. Treatments were arranged in a $2 \times 2 \times 2$ factorial within a randomized complete block design. Protease inclusion was either 0 or $2 \%$. Diet composition was either all-vegetable protein or an $8 \%$ porcine meat and bone meal inclusion. Diets were fed as unprocessed mash or ground pellets that were steam conditioned at $70^{\circ} \mathrm{C}$ and extruded through a 4 x $38 \mathrm{~mm}$ pellet die. Pellets were ground prior to feeding to 
eliminate potentially confounding feed form effects. All diets were formulated to be $85 \%$ of crude protein and digestible amino acid recommendations for young broilers. In addition, two unprocessed mash diets representing the all-vegetable protein or $8 \%$ porcine meat and bone meal inclusion were formulated to be $100 \%$ of crude protein and digestible amino acid recommendations and were fed as controls. Dietary treatments were fed to nine replicate raised wire cages of eight straight-run Hubbard x Cobb broiler chicks for $21 \mathrm{~d}$. Protease activity was confirmed post pelleting and expressed in tyrosine releasing units that compare the absorbance of tyrosine liberated by protease digested casein to a standard curve generated by a tyrosine dilution. Protease and Degree of Processing interacted to effect chick weight gain and feed conversion ratio (FCR) $(\mathrm{P}<0.05)$. Protease applied to pelleted diets improved $21 \mathrm{~d}$ weight gain by $57 \mathrm{~g}$ and decreased $21 \mathrm{~d}$ FCR by 0.07 . Similar improvements were not observed in unprocessed mash diets. Linear contrasts clarified that protease applied to pelleted diets was most beneficial for all vegetable protein compositions $(\mathrm{P}<0.05)$. Diet Composition and Degree of Processing interacted to effect FCR $(\mathrm{P}<0.05)$. Meat and bone meal inclusion increased feed conversion ratio in unprocessed mash diets but not pelleted diets. Protease efficacy was influenced by diet composition and degree of processing. 


\section{Acknowledgements}

I would first like to thank my major advisor, Dr. Joseph Moritz, whose continued support has led me down a path of success. I will be forever grateful for the many opportunities to better myself and for the continuous support, guidance, and friendship. Next, I would like to thank my committee members, Dr. Jacek Jaczenski and Dr. Eugene Felton, for their continued support throughout my research and graduate courses. Thank you to the WVU Animal Science farm staff and faculty, especially Mr. Rick Wood, for their assistance during my time as a Graduate Research Assistant. I would like to extend my gratitude to Mrs. Tammy Webster and Ms. Becky DeVito. Without their continuous support and assistance in the laboratory, my research would not have been possible. Thank you to my fellow lab mates: John Boney, Brian Glover, Kolby Foltz, and Tyler Rigby. My success would not have been possible without their help. Lastly, I would like to thank my parents, Karen and Robert, my step-mother, Becky, my sisters, Rebecca, Shelly, and Robin, my grandfather, Butch, my late grandmothers, Elvira and Philena, and my boyfriend, Brian. Their encouragement and support throughout my time at WVU has allowed me to reach this milestone in my life. 


\section{TABLE OF CONTENTS}

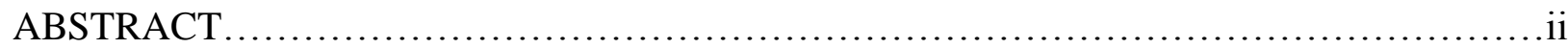

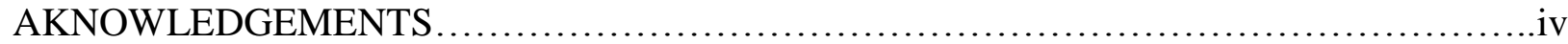

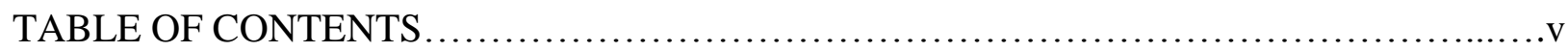

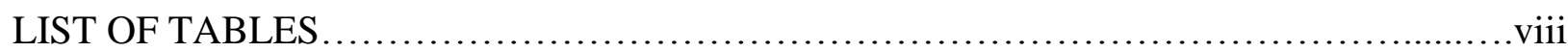

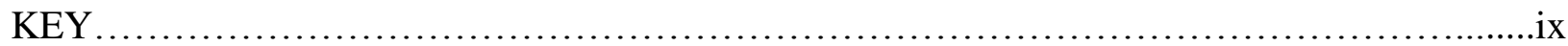

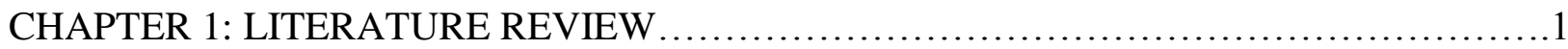

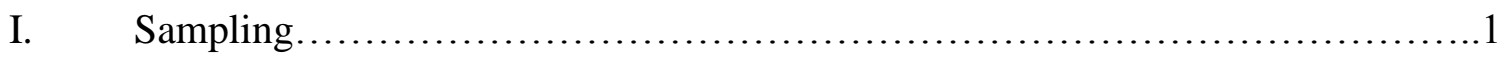

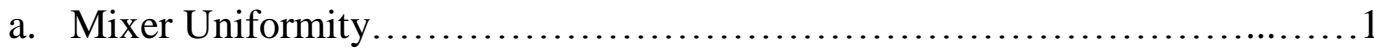

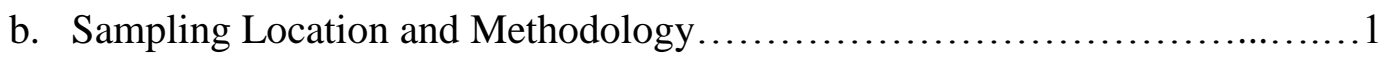

c. Nutrient Analysis.....................................................2

d. Methionine and Lysine............................................

II. Exogenous Enzyme Use in Feed.........................................5

a. Enzyme Cocktails................................................5

b. Heat Stability of Exogenous Enzymes...............................6

c. Proteases..........................................................

d. Enzymatic Recovery Assays......................................... 7

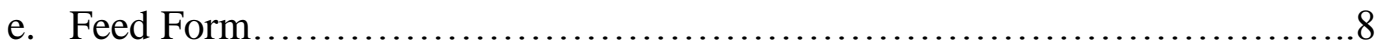

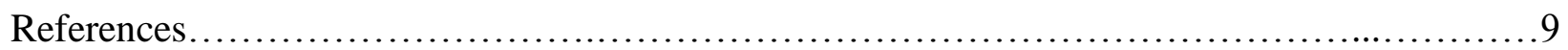

CHAPTER 2: Effect of mixing and sampling methodologies on nutrient analysis...................13

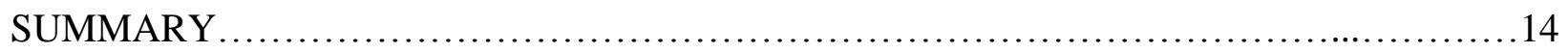


DESCRIPTION OF PROBLEM.......................................................

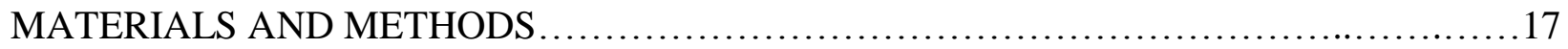

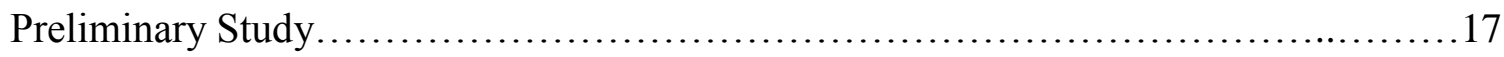

Diet Formulation and Feed Manufacture.............................................18

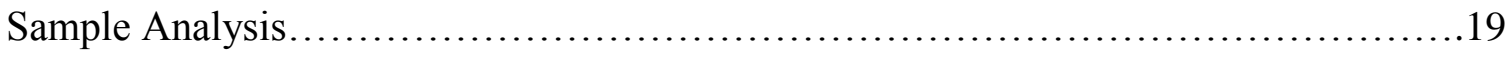

Statistical Analysis.................................................................. 19

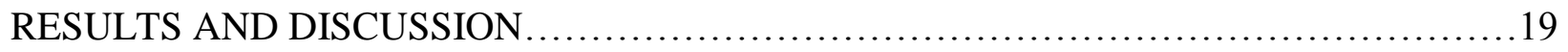

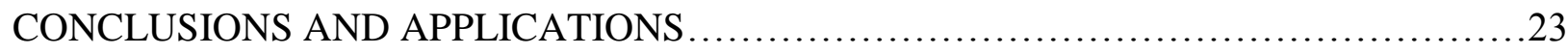

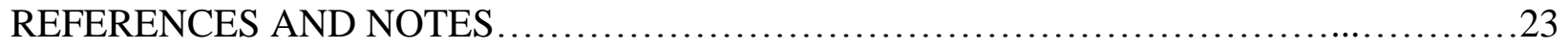

Table 1: Analyzed Nutrients of Corn, Soybean Meal, Meat and Bone Meal, and Dried Distillers

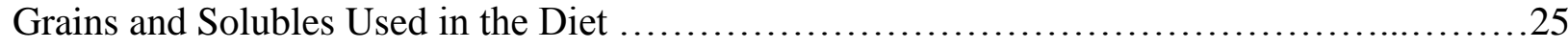

Table 2: Ingredients and Calculated Nutrient Composition of a Broiler Finisher Diet............26

Table 3: Coefficient of Variation of a Corn-Salt Mixture and the Complete Feed Mixed for 30

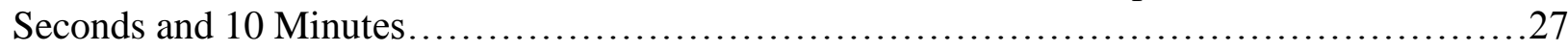

Table 4: Treatment Means of Mixing, Sampling, and Blending Techniques...................28

CHAPTER 3: Efficacy of a novel protease provided to broiler chicks in diets that vary in

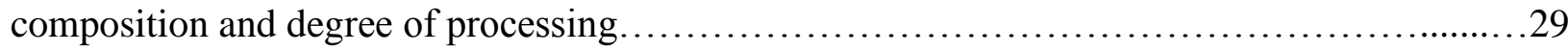

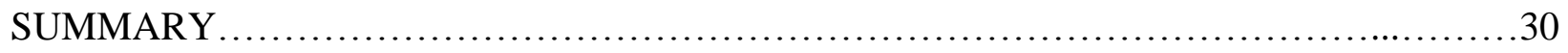

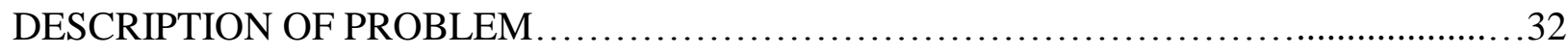

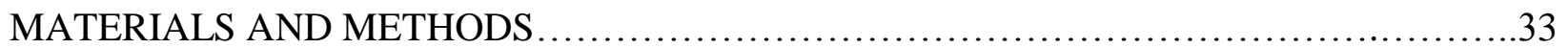

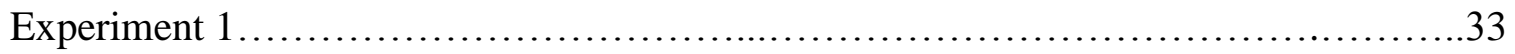


Protease Assay.............................................................. 33

Feed Manufacture........................................................... 34

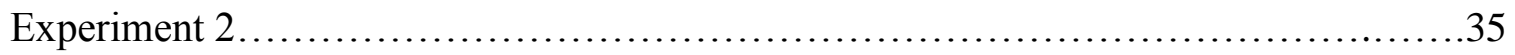

Feed Manufacture....................................................... 35

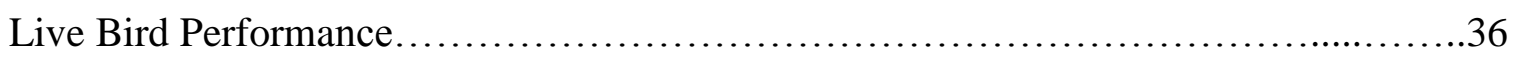

Statistical Analysis....................................................... 37

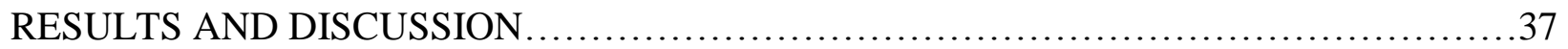

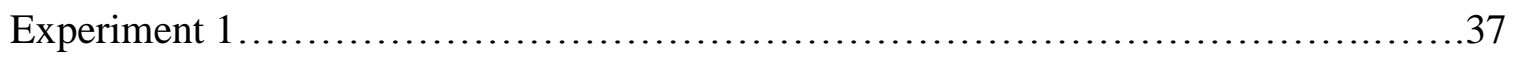

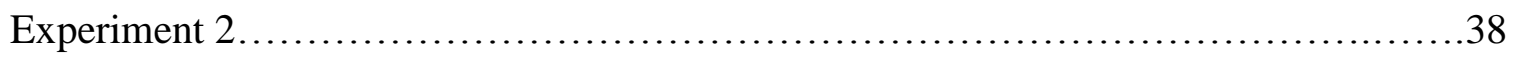

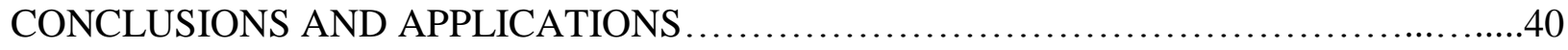

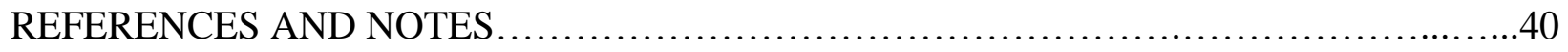

Table 1: Ingredients and Calculated Nutrient Composition of Broiler Starter Diets.............43

Table 2: Determination of Dosage of Protease to be Utilized in Broiler Diets Using Unprocessed

Mash.......................................................................... 44

Table 3: Determination of Conditioning Temperature for $2 \%$ Inclusion of Protease in an All

Vegetable Protein Diet.........................................................44

Table 4: Descriptive Feed Manufacture Data of Experiment 2 ...........................45

Table 5: Protease Activity Obtained From Experiment 2 Using the Tyrosine Releasing Unit

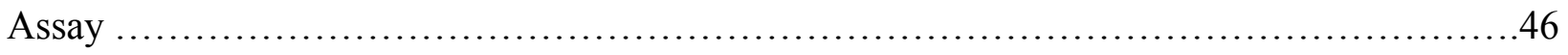


Table 6: Effects of a Novel Protease Included in Diets that Differ in Substrate and Processing on

Broiler 0-21 Day Performance..................................................47

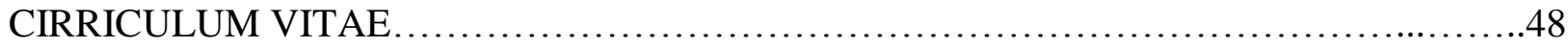

\section{LIST OF TABLES}

Chapter 2 Tables

Table 1: Analyzed Nutrients of Corn, Soybean Meal, Meat and Bone Meal, and Dried Distillers

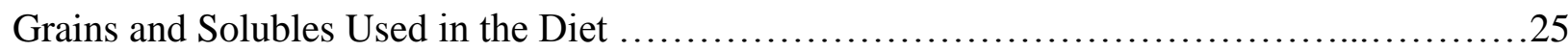

Table 2: Ingredients and Calculated Nutrient Composition of a Broiler Finisher Diet...........26

Table 3: Coefficient of Variation of a Corn-Salt Mixture and the Complete Feed Mixed for 30

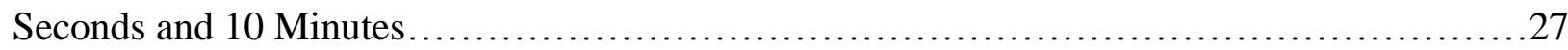

Table 4: Treatment Means of Mixing, Sampling, and Blending Techniques..................28

Chapter 3 Tables

Table 1: Ingredients and Calculated Nutrient Composition of Broiler Starter Diets.

Table 2: Determination of Dosage of Protease to be Utilized in Broiler Diets Using Unprocessed

Mash....

Table 3: Determination of Conditioning Temperature for 2\% Inclusion of Protease in an All

Vegetable Protein Diet.

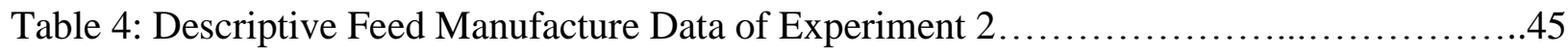

Table 5: Protease Activity Obtained From Experiment 2 Using the Tyrosine Releasing Unit

Assay 
Table 6: Effects of a Novel Protease Included in Diets that Differ in Substrate and Processing on

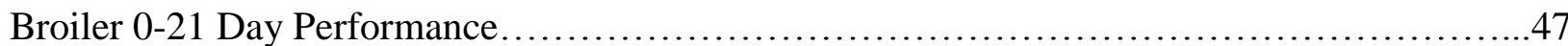

KEY

Chapter 1

1. Amino acids- AA

2. Exogenous enzyme cocktail- EEC

3. Feed conversion ratio- FCR

4. Pellet durability index- PDI

5. Mixer added fat- MAF

Chapter 2

1. Coefficient of variation- $\mathrm{CV}$

2. Dried distillers grains with solubles- DDGS

3. Association of analytical communities- AOAC

4. Crude protein- $\mathrm{CP}$

Chapter 3

1. Tyrosine releasing units per gram- TU/g

2. Mixer added fat- MAF

3. Absorbance- Abs

4. Meat and bone meal- M\&B

5. Hot pellet temperature- HPT

6. Exogenous enzyme complex- EEC

7. Feed conversion ratio- FCR 


\section{CHAPTER 1: LITERATURE REVIEW}

\section{Sampling}

\section{A. Mixer Uniformity}

Feed and feed manufacture account for $60-70 \%$ of total production costs associated with a modern poultry operation. Two factors in the feed mill that are critical for optimal broiler performance are utilizing a homogenized, pelleted diet, and ensuring that the feed mill is producing the diet formulated by the nutritionist. Quality control measures may be employed by integrators by taking samples during the feed manufacture process to ensure proper batching and pelleting. One method for ensuring that the diet is homogenized is taking samples from the mixer to test for uniformity [1]. When testing for mixer uniformity, various tracers such as chloride ion, sodium ion, colored iron particles, chromium, and crystalline amino acids can be analyzed for coefficient of variation [1-3]. It is imperative that animals, especially animals with a low feed intake, consume a homogenous diet. This will benefit both animal health and performance [1, 2].

\section{B. Sampling Location and Methodology}

Nutritionists formulate diets based on the animal's dietary needs, guaranteed analysis of ingredients, and least-cost formulation. Diets are formulated for specific requirements that coincide with a specific growth period. Samples can be taken during the pelleting process to confirm that the feed mill is producing the correct diet; however, there are many different locations that samples can be taken from and various methodologies that can be utilized. The most accessible locations are post extrusion from the pellet die, the cooler deck, and the finished feed during loading or bagging. After review of literature, no peer-reviewed journal articles were found that compared samples of pelleted feed from multiple locations. 
Past literature shows that the number of samples collected may determine the perception of whether or not the mixture is homogenous $[1,2]$. For example, collecting two samples and testing for chloride ion content may demonstrate a precise analysis (similar values), but the values may not be accurate (representative of the feed as a whole). Creger demonstrated through a mixing and sampling study that collecting more samples (up to nine) accurately determined diet homogeneity [1]. While analyzing nutrient content of broiler litter, Tasistro et al. states that when data sets consist of relatively small samples, then the sample variance might not provide a good approximation of the population variance [4]. Tasistro et al. also concluded that after the litter had been removed from the house, the samples were less variable because they had undergone a degree of mixing [4].

\section{Nutrient Analysis}

The Association of Analytical Communities (AOAC) is responsible for developing official methods of analysis (OMA) for microbiological and chemical standards, including feeds, dietary supplements, soil, pharmaceuticals, etc. The most common OMA when dealing with livestock feeds are those involved in proximate analysis: moisture, ash, crude protein, crude fat, and crude fiber. A "crude" value is simply an approximated value. Crude protein is the measure of all protein and non-protein nitrogen. Crude fat is a measure of triglycerides and other lipidlike substances such as waxes, steroids, pigments, etc. Crude fiber is a measure of mainly structural plant material within vegetable components of the diet.

When analyzing for moisture, approximately two grams of feed is placed into a drying oven at 100 degrees Celsius for 16 hours. Once the sample is cooled, it is weighed and the new weight is divided by the original weight, then multiplied by 100 to acquire percent moisture [5]. Ash analysis is performed in a similar manner. Approximately two grams of feed will be placed 
in a crucible in a temperature controlled furnace at 600 degrees Celsius for two hours. The sample is weighed back and the new weight is subtracted from the original weight. This value is then divided by the original weight and multiplied by 100 to acquire percent ash [6].

Crude protein, crude fat, and crude fiber analyses can be performed in multiple ways. The most common and well-known method for crude protein is the Copper Catalyst Kjeldahl Method [7]. There are three main steps in this method: digestion, distillation, and titration. Digestion occurs when sulfuric acid and a copper catalyst are added to a one gram sample of feed in a 500$800 \mathrm{~mL}$ Kjeldahl flask. The flask is then placed on a burner that is adjusted to bring $250 \mathrm{~mL}_{2} \mathrm{O}$ at 25 degrees Celsius to a boil in five minutes. When white fumes appear in the tube, it is heated for an additional 90 minutes. The flask is allowed approximately 10 minutes to cool, diluted 250 mL with $\mathrm{H}_{2} \mathrm{O}$, and allowed to continue to cool to room temperature. An electronic Kjeldahl apparatus can then be used to automatically titrate the acidic sample solution with a sodium hydroxide solution. The reading from the apparatus can then be used to calculate crude protein, or percent nitrogen [7].

The proper crude fat analysis, or ether extract, depends on the standard. For animal feed, anhydrous ether is prepared as outlined in AOAC Official Method 920.39 [8]. A two gram sample of feed is obtained and placed in a soxhlet apparatus. Ether is allowed to pass through the apparatus at a condensation rate of 2/3 drops per second for 16 hours. The apparatus is removed from the heat source and samples are dried for 30 minutes. Samples are weighed back and the new weight is subtracted from the original weight. This value is divided by the new sample weight, and multiplied by 100 to obtain the crude fat percentage [8].

The most complex proximate analysis procedure is crude fiber. The feed sample will first need to be subject to moisture and ether extract analysis using specific sample weights and 
temperatures outlined in AOAC Official Method 692.09 [9]. After ether extraction, the sample is added to an Oklahoma filter screen and the screen is precoated with sulfuric acid and a ceramic fiber mixture. The Oklahoma filter screen is then attached to a vacuum flask with the suction turned on. Boiling $\mathrm{H}_{2} \mathrm{O}$ is added and the filter is removed from the beaker to drain excess $\mathrm{H}_{2} \mathrm{O}$ from the line. The filter is returned to the beaker and boiling sodium hydroxide is added and boiled for 30 minutes. The beaker is then removed from the heat and the filter screen is precoated a second time. The sample is filtered again using different reagents as described in AOAC Official Method 692.09 [9]. The sample is dried for two hours at 130 degrees Celsius. Once cooled and weighed, the sample is ignited for 30 minutes at 600 degrees Celsius, cooled, and reweighed. Crude fiber percentage is then obtainable using the equations outlined in AOAC Official Method 692.09 [9]. It is important to note that, due to the numerous steps in this method, variability and percent error are very high when the assay is repeated.

\section{Methionine and Lysine}

Methionine and lysine are the first and second limiting amino acids (AA) for broilers [10]. In commercial diets, these AA are supplemented in crystalline form as DL-methionine and lysine- $\mathrm{HCl}$. However, the price of supplemental AA, along with other ingredients, has been increasing [10]. Higher costs are causing commercial companies to lower their supplemental AA inclusion in poultry diets [10]. This is resulting in impaired FCR and breast meat yield [10-12]. Kalinowski et al. [12] conducted a study that compared methionine and cystine requirements for fast and slow feathering broilers. The authors stated that increasing supplemental methionine concentrations of a diet that was deficient in methionine (70\% NRC requirements) improved FCR in a linear manner. Zhai et al. [10] also observed improvements in FCR along with increases in carcass yield and decreased abdominal fat. Similar results have been observed when 
experiments were conducted on broilers consuming lysine deficient versus lysine adequate diets $[10,13]$.

\section{Exogenous Enzyme Use in Feed}

\section{A. Enzyme Cocktails}

Although exogenous enzyme research has been ongoing for decades, the commercial use of exogenous enzymes in feed is much more recent. This is mainly due to the rise in feed ingredient costs and the public's expectations of pollution control from animal agriculture [14, 15]. Generally, the endogenous proteases synthesized in the bird and released in the gastrointestinal tract are considered sufficient for optimal protein and amino acid utilization [14]. Digestibility reports for poultry, however, reveal that endogenous enzymes may not be enough for complete digestion [14-16]. Introduction of exogenous enzymes into the diet aid in utilization of these typically unavailable nutrients, such as large, globular proteins, non-starch polysaccharides, and phytate.

The most established enzyme in both research and commercial poultry markets is phytase [17-19]. Phytase targets molecules of phytate by hydrolyzing the molecule, releasing a usable, inorganic molecule of phosphorus. Other enzyme products, however, are available as exogenous enzyme cocktails (EEC). These EEC contain various combinations of different exogenous enzymes (amylases, proteases, xylanases, glucanase, cellulose, mannanase, and pectinase) [20]. While research shows that unconditioned mash diets containing EEC improve bird performance, different results have been obtained when the diets are pelleted [20]. During pelleting, feed is exposed to high moisture, pressure, and temperatures, which affects both nutrients in the diet and any enzymes used. Some phytases have been shown to lose efficacy at $70^{\circ} \mathrm{C}$, xylanases at $105^{\circ} \mathrm{C}$, 
and glucanases at $75^{\circ} \mathrm{C}$ [20]. Due to this loss in efficacy, it is thought that live bird performance data may be more useful than enzymatic recovery assays.

\section{B. Heat Stability of Exogenous Enzymes}

Pelleting broiler feed has many benefits for both the integrator and the grower, including increases in feed intake and live weight gain, improved FCR, decreased feed selection and wastage by the bird, and improved palatability [22, 23, 26-29]. However, pelleting can also be detrimental due to the exposure to high moisture, pressure, and temperature. Amino acids may become unavailable due to denaturing, loss of nutrients may occur due to attrition throughout the feed mill, and any exogenous enzymes could lose activity due to denaturation [24, 25]. One way to combat performance detriments is to increase the amount of fat added at the mixer to increase lubrication and decrease frictional heat in the pellet die (although this will cause detriments in physical feed properties, such as PDI) [22, 24, 25].

Typically, commercial broiler diets will contain less than $3 \%$ mixer-added fat (MAF). Increasing MAF to 3\% or more has shown improved broiler performance, improved nutrient utilization, improved enzyme efficacy, decreased post extrusion pellet temperature, and reduced electrical energy usage during pelleting $[22,24]$. The decreased post extrusion temperature suggests that fat added at the mixer increases die lubrication, therefore decreasing the frictional heat between the feed and the pellet die [24]. Improved nutrient utilization and enzyme efficacy suggests that decreased frictional heat also decreased the chances of nutrient and enzyme degradation [22]. It has also been proposed that enzyme inactivation is caused by being treated with saturated steam during conditioning [25]. It is possible that decreased pellet quality is caused by MAF coating feed particles and lubricating the pellet die, interfering with starch gelatinization and protein gelation $[24,25]$. 


\section{Proteases}

Poultry feed often contains complex, indigestible compounds, such as large, globular proteins [26]. Proteases may be added to the diet to increase crude protein and amino acid digestibility. One protease that has received ample attention in research is PWD-1 keratinase, derived from Bacillus licheniformis [26-29]. The enzyme was discovered when Shih [26] noticed that shed feathers had completely disintegrated when they were included in the excreta that had undergone laboratory digestion. Since the discovery of PWD-1 keratinase, or Versazyme, it has demonstrated improvements in amino acid digestibility and performance when added to broiler diets [27-29].

Odetallah et al. [27] observed increased body weight and decreased digesta viscosity when diets containing PWD-1 keratinase were fed to broilers. However, authors stated that performance improvements were more prominent when the enzyme was added to control diets (93\% NRC requirements for $\mathrm{CP}$ ) versus experimental diets (78\% NRC requirements for $\mathrm{CP}$ ). Authors speculated that this is because keratinase is a broad-spectrum enzyme that has many different substrates, therefore is able to break down many different peptides, which were more prevalent in the control diet [27]. Wang et al. [28] also observed increased body weight of broilers fed diets incorporating PWD-1 keratinase and formulated to be $95 \%$ of NRC requirements for CP. Additionally, the authors stated that broilers fed diets that contained the enzyme demonstrated $1.62 \%$ improvement in FCR and $1.68 \%$ improvement in breast meat yield [28]. More recently, Stark et al. [29] performed enzymatic recovery assays for PWD-1 keratinase on pelleted diets. Despite low recovery, bird performance still improved when broilers were fed diets containing keratinase. The authors observed increased weight gain and improved FCR (783 to $838 \mathrm{~g}$ and 1.73 to 1.56 , respectively). 


\section{Enzymatic Recovery Assays}

It is difficult for a commercial company to select an EEC to use in broiler diets due to the high variability in substrate specificity, activity, and stability [25]. Also, in vitro results often vary from in vivo results because gastrointestinal tract conditions are more dynamic compared to isolated lab conditions [23, 25]. Furthermore, data for the effects of single-enzyme activities are unattainable for EEC [19]. While there has been very little research involving single enzymes, particularly proteases, in poultry diets $[18,19]$, single protease activity data that is available shows high variation in activity, both in vitro and in vivo, because there are many different types of proteases that have different substrate specificities. For example, trypsin is an endogenous serine protease that targets peptide bonds involving lysine and arginine [18]. These concerns are causing in vitro enzyme assays to be developed that simulate gut conditions; exposing feed with enzyme to different $\mathrm{pH}$ and endogenous enzymes present in the gut [25].

Enzyme activity assays have also been developed that are non-specific to a substrate. A non-specific protease assay developed by Sigma-Aldrich, uses casein as a substrate [34]. Tyrosine is liberated when the protease digests the casein [34]. It can be performed using a buffer, casein solution, trichloroacetic acid solution, and a sodium carbonate solution for dilution [31]. The tyrosine absorbance readings from a spectrophotometer indicate how much tyrosine was liberated, and the readings are then used in a calculation to yield protease activity [34].

\section{E. Feed Form}

Broiler feed can be produced in three forms: mash, crumble, and pellet. These feed forms have different effects on bird growth and performance [27, 29-32]. Mash is simply a blend of ground ingredients that have not been exposed to conditioning or pelleting. Crumbles have also 
been exposed to pelleting and have been ground via roller mill to a particle size between that of a mash and an in-tact pelleted diet.

Since feed and feed manufacture represent $60-70 \%$ of the costs of broiler production, it is imperative that integrated poultry growers are able to efficiently produce feed that birds are able to efficiently utilize [26, 33]. Utilizing an improved feed form, such as pellets, has demonstrated increased live weight gain, increase feed intake, improved feed conversion ratio (FCR), improvements in production energy, decreased ingredient segregation, decreased feed wastage, and a decrease in pathogens when compared to a mash diet [30-33]. The degree that these improvements are observed depends on the pellet quality [30-33]. Increasing pellet quality by $10 \%$ has been shown to increase carcass weight by $10 \mathrm{~g}$, increase breast weight by $4 \mathrm{~g}$, and improve FCR by 0.0004 for Cobb x Cobb 500 broilers despite an increase in feed intake [32, 33]. Glover et al. [31] also observed performance benefits, including a 3 point FCR improvement and decreased feed intake coupled with similar live weight gain, for Hubbard x Cobb 500 broilers fed an improved pellet quality diet (70\% crumble/pellet) verses a standard pellet quality diet (50\% crumble/pellet). Birds fed pelleted diets are able to consume the same amount of feed as those fed a mash diet in a shorter amount of time [30]. Reduced eating time decreases energy expenditure and birds are able to utilize more energy for growth and maintenance [30]. Since birds fed pelleted diets are able to consume a set amount of feed more quickly, they are able to consume more "meals" per day than birds fed a mash diet [30]. These observations could explain why birds fed pelleted diets consume more feed while demonstrating improved performance, and could justify costs associated with the pelleting process [30].

\section{References}

1. Creger, C. R. 1957. A study of distribution of micro-ingredients in mixed feeds. MS Thesis. Kansas State Univ., Manhattan. 
2. McCoy, R. A., K. C. Behnke, J. D. Hancock, and R. R. McEllhiney. 1994. Effect of mixing uniformity on broiler chick performance. Poult Sci. 73:443-451.

3. Clark, P. M., K. C. Behnke, and D. R. Poole. 2007. Effects of marker selection and mix time on the coefficient of variation (mix uniformity) of broiler feed. J Appl Poult Res. 16:464-470.

4. Tasistro, A. S., D. E. Kissel, and P. B. Bush. 2004. Sampling broiler litter: how many samples are needed? J Appl Poult Res. 13:163-170.

5. Official Methods of Analysis of AOAC INTERNATIONAL (2000) $17^{\text {th }}$ Ed., AOAC INTERNATIONAL, Gaithersburg, MD, USA, Official Method 934.01.

6. Official Methods of Analysis of AOAC INTERNATIONAL (2000) $17^{\text {th }}$ Ed., AOAC INTERNATIONAL, Gaithersburg, MD, USA, Official Method 942.05.

7. Official Methods of Analysis of AOAC INTERNATIONAL (2000) $17^{\text {th }}$ Ed., AOAC INTERNATIONAL, Gaithersburg, MD, USA, Official Method 984.13.

8. Official Methods of Analysis of AOAC INTERNATIONAL (2000) $17^{\text {th }}$ Ed., AOAC INTERNATIONAL, Gaithersburg, MD, USA, Official Method 920.39.

9. Official Methods of Analysis of AOAC INTERNATIONAL (2000) $17^{\text {th }}$ Ed., AOAC INTERNATIONAL, Gaithersburg, MD, USA, Official Method 692.09.

10. Zhai, W., E. D. Peebles, M. W. Schilling, and Y. Mercier. 2016. Effects of dietary lysine and methionine supplementation on Ross 708 male broilers from 21 to $42 \mathrm{~d}$ of age (I): growth performance, meat yield, and cost effectiveness. J Appl Poult Res. 0:1-15.

11. Hickling, D., W. Guenter, and M. E. Jackson. 1990. The effects of dietary methionine and lysine on broiler chicken performance and breast meat yield. Can J Anim Sci. 70:673-678.

12. Kalinowski, A., E. T. Moran, Jr., and C. Wyatt. 2003. Methionine and cystine requirements of slow- and fast-feathering male broilers from zero to three weeks of age. Poult Sci. 82:1423-1427.

13. Wang, H., C. Zhang, Y. Mi, and M. T. Kidd. 2014. Copper and lysine amino acid density responses in commercial broilers. J Appl Poult Res. 23:470-477.

14. Freitas, D. M., S. L. Vieira, C. R. Angel, A. Favero, and A. Maiorka. 2011. Performance and nutrient utilization of broilers fed diets supplemented with a novel mono-component protease. J Appl Poult Res. 20:322-334. 
15. Angel, C. R., W. Saylor, S. L. Vieira, and N. Ward. 2011. Effects of a monocomponent protease on performance and protein utilization in 7- to 22-day-old broiler chickens. Poult Sci. 90:2281-2286.

16. Wang, X. and C. M. Parsons. 1998. Effect of raw material source, processing systems, and processing temperatures on amino acid digestibility of meat and bone meals. Poult Sci. 77:834-841.

17. Yan, F., C. A. Fritts, and P.W. Waldroup. 2003. Evaluation of modified dietary phosphorus levels with and without phytase supplementation on live performance and fecal phosphorus levels in broiler diets. 1. full-term feeding recommendations. J Appl Poult Res. 12:174-182.

18. Shelton, J. L. and L. L. Southern. 2006. Effects of phytase addition with or without a trace mineral premix on growth performance, bone response variables, and tissue mineral concentration in commercial broilers. J Appl Poult Res. 15:94-102.

19. Loop, S. A., K. G. S. Lilly, L. K. Shires, C. K. Gehring, K. R. Beaman, M. E. Persia, and J. S. Moritz. 2012. The phytase analytical activity of pelleted diets may not adequately describe efficacy in the bird. J Appl Poult Res. 21:492-501.

20. Beaman, K. R., K. G. S. Lilly, C. K. Gehring, P. J. Turk, and J. S. Moritz. 2012. Influence of pelleting on the efficacy of an exogenous enzyme cocktail using broiler performance and metabolism. J Appl Poult Res. 21:744-756.

21. Malathi, V. and G. Devegowda. 2001. In vitro evaluation on nonstarch polysaccharide digestibility of feed ingredients by enzymes. Poult Sci. 80:302-305.

22. Corey, A. M., K. G. S. Wamsley, T. S. Winowiski, and J. S. Moritz. 2014. Effects of calcium lignosulfonate, mixer-added fat, and feed form on feed manufacture and broiler performance. J. Appl. Poult. Res. 23:418-428.

23. Chewning, C. G., C. R. Stark, and J. Brake. 2012. Effects of particle size and feed form on broiler performance. J. Appl. Poult. Res. 21:830-837.

24. Gehring, C. K., K. G. S. Lilly, L. K. Shires, K. R. Beaman, S. A. Loop, and J. S. Moritz. 2011. Increasing mixer-added fat reduces the electrical energy required for pelleting and improves exogenous enzyme efficacy for broilers. J. Appl. Poult. Res. 20:75-89.

25. Lamp, A. E., A. M. Evans, and J. S. Moritz. 2015. The effects of pelleting and glucanase supplementation in hulled barley based diets on feed manufacture, broiler performance, and digesta viscosity. J. Appl. Poult. Res. 24:295-303.

26. Shih, J. C. H. 1993. Recent development in poultry waste digestion and feather utilization - a review. Poult Sci. 72:617-620. 
27. Odetallah, N. H., J. J. Wang, J. D. Garlich, and J. C. H. Shih. 2003. Keratinase in starter diets improves growth of broiler chicks. Poult Sci. 82:664-670.

28. Wang, J. J., J. D. Garlich, and J. C. H. Shih. 2006. Beneficial effects of versazyme, a keratinase feed additive, on body weight, feed conversion, and breast yield of broiler chickens. J Appl Poult Res. 15:544-550.

29. Stark, C. R., B. E. Spencer, J. C. H. Shih, C. G. Chewning, and J. J. Wang. 2009. Evaluation of keratinase stability in pelleted broiler diets. J Appl Poult Res. 18:30-33.

30. Jensen, L. S., L. H. Merrill, C. V. Reddy, and J. McGinnis. 1962. Observations on eating patterns and rate of food passage of birds fed pelleted and unpelleted diets. Poult. Sci. 41:1414-1419.

31. Glover, B. G., K. L. Foltz, I. Holásková, and J. S. Moritz. 2016. Effects of modest improvements in pellet quality and experiment pen size on broiler chicken performance. J. Appl. Poult. Res. 25:21-28.

32. Lemons, M. E. and J. S. Moritz. 2016. The effect of feeder space access and crumble- or pellet-to-fine ratio on 38-day-old broiler performance. J. Appl. Poult. Res. 25:12-20.

33. Lilly, K. G. S., C. K. Gehring, K. R. Beaman, P. J. Turk, M. Sperow, and J. S. Moritz. 2011. Examining the relationships between pellet quality, broiler performance, and bird sex. J. Appl. Poult. Res. 20:231-239.

34. Cupp-Enyard, C. 2008. Sigma's non-specific protease activity assay - casein as a substrate. J. Vis. Exp. 19:889. 
CHAPTER 2: Effect of mixing and sampling method on pelleted feed nutrient analysis and diet formulation accordance

D.A. Reese, K.L. Foltz, and J.S. Moritz

Division of Animal and Nutritional Sciences, West Virginia University, Morgantown, West Virginia, 26506

Phone: 304-293-1911

Fax: 304-293-2232 
SUMMARY Proper poultry feeding requires a homogenous mixture of macro and micro ingredients to ensure feed nutrients are being supplied to meet bird requirements. Samples of complete feed may be taken during manufacture and analyzed for nutrient content in order to estimate if nutrients are present in feed in accordance to diet formulation. However, variables associated with mixing and feed sampling may influence the results of nutrient analysis, thus over or under estimating the formula comparison. The objective of this study was to vary mix time, sample location, sample number, and sample blending technique on nutrient analysis. Ingredients were mixed in a single screw vertical mixer for either 30 seconds or 10 minutes. Samples were taken from either the pellet die or from the finished feed post cooling, conveyance, and bagging. Samples were blended together from two or 10 samples during manufacture. Blending occurred from either combining samples and mixing by hand or using a sample splitting device. Proximate analysis and free supplemental DL-methionine and L-lysine-HCl were determined on each blended sample and standardized for moisture content. A preliminary study was performed to determine mixer coefficient of variation and showed that ingredients were homogenous when a corn-salt mix was utilized and mixed for 10 minutes $(\mathrm{P}<0.05)$. In the primary study, crude fat and free supplemental DL-methionine were affected by mix time $(\mathrm{P}<0.05)$. The 10 minute mix time produced values for crude fat and free supplemental DLmethionine that were lower and higher, respectively, compared to the $30 \mathrm{sec}$ mix time and agreed more with the calculated nutrient profile and diet formulation. Free supplemental DL-methionine was also affected by sampling location $(\mathrm{P}<0.05)$. Samples obtained at the pellet die were higher and agreed more with the calculated nutrient profile compared to finished feed samples obtained at the sack off bin. Total ash was affected by a sampling location and sampling technique interaction $(\mathrm{P}<0.05)$. Samples collected at the pellet die were in closer agreement regardless of 
sample number; whereas, finished feed samples obtained at the sack off bin were affected more by sample number. These data suggest that mixing and sampling variables can effect nutrient analysis and sampling protocols should be utilized to best estimate if nutrients present in feed are in agreement with diet formulation. The particular conditions of the study suggest that analysis of free supplemental DL-methionine from samples obtained at the pellet die may be the best metric for determining pelleted diet homogeneity and accordance relative to diet formulation.

Keywords: mixing time, blending technique, sample number, sample location, proximate analysis 


\section{DESCRIPTION OF PROBLEM}

Feed and feed manufacture account for $60-70 \%$ of the total costs of production associated with commercial poultry rearing. The use of a homogenized, pelleted diet optimizes bird performance and maximizes production efficiency [1-3]. A homogenized diet has been described as ingredients being mixed to achieve nutrient coefficient of variation (CV) of less than $10 \%$ [3]. McCoy et al. [2] evaluated mixer effects on $28 \mathrm{~d}$ broiler performance and observed increases in average daily gain (23.6 vs. 30.3 g), average daily feed intake (43.1 vs. 52.7 g), gain:feed (0.548 vs. 0.575$)$ and a decrease in mortality (12.0 vs. $0 \%)$ as mixer revolutions and presumably diet homogeneity increased, respectively.

Different nutrients and additives have been used as markers to determine mixer uniformity. Accuracy of the laboratory assay for the specific marker, as well as ease and cost of the assay, are important for marker selection [3]. Pfost et al. [4] suggested selecting ingredient markers that have similar physical properties, and not to utilize nutrient markers that are found in multiple ingredients (e.g., crude protein). Clark et al. [3] conducted a mixer uniformity study that utilized a $454 \mathrm{~kg}$ capacity double ribbon mixer and complete feed. These authors found that analyses for nutrients found in multiple ingredients (crude protein, chloride ion, phosphorus, and manganese) did not differ with varying mix times. However, analyses for DL-methionine and Llysine- $\mathrm{HCl}$, demonstrated that mixer $\mathrm{CV}$ decreased as mix time increased from 30 seconds to 5 minutes (23.86 to $9.47 \%$ and 19.75 to $8.7 \%$, respectively).

In commercial feed manufacture, once diets are mixed to a uniform consistency, feed will be conveyed and packaged as mash or pelleted, cooled, and packaged prior to transport and feeding. Commercial broilers are provided pelleted diets due to ease of handling, decreased feed wastage at the feed pan, decreased energy expenditure in prehension of feed, decreased 
ingredient selection, and decreased probability of microbial contamination due to exposure to high temperature and pressure [5]. Conditions of high temperature, pressure, and moisture cause the gelation of proteins and gelatinization of starch that enable pellet formation [5]. However, attrition of pellets can occur during conveyance, cooling, packaging, transportation to the growout-barn, and conveyance through the barn. Attrition may lead to significant ingredient and subsequent nutrient segregation of feed. Confirmation that the feed mill is accurately producing an intended diet formulation could be an important control point for feed quality assurance. Depending on the method of pellet sampling in the feed mill, and the particular nutrient analysis, the comparison to calculated nutrients and ingredient inclusions of the formulation may be over or underestimated. Data does not exist on proper pellet sampling technique within the feed mill to best determine pelleted feed homogeneity and accordance to diet formulation. The objective of this study was to manipulate mixing and pellet sampling variables in the feed mill and compare sample nutrient analyses with diet formulation in order to recommend a sampling method with increased accuracy.

\section{MATERIALS AND METHODS}

\section{Preliminary Study}

A preliminary study was conducted to determine the proper mix time of a $0.91 \mathrm{MT}$ vertical screw horizontal mixer [6] using a corn-salt diet at the West Virginia University pilot feed mill. Three $136 \mathrm{~kg}$ batches of feed containing $3 \%$ iodized salt $(\mathrm{NaCl})$ were mixed for 30 sec and three similarly formulated $136 \mathrm{~kg}$ batches of feed were mixed for $10 \mathrm{~min}$. Ten samples were taken from 10 different locations in the mixer after each mixing period (30 sec and $10 \mathrm{~min}$ ) and analyzed for chloride ion concentration using Quantab Test Strips [7]. This procedure was 
repeated using similar quantities and replicates of a complete broiler diet (corn and soybean meal based). Coefficient of variation was calculated using the obtained samples and following equation:

$$
\begin{gathered}
\% \mathrm{CV}=\mathrm{s}^{2} / \mathrm{m} \times 100 \\
\mathrm{~m}=\left(\sum \mathrm{x}_{\mathrm{i}}\right) / \mathrm{n} \\
\mathrm{s}^{2}=\left[\sum\left(\mathrm{x}_{\mathrm{i}}{ }^{2}\right)-\mathrm{nm}^{2}\right] / \mathrm{n}-1
\end{gathered}
$$

\section{Diet Formulation and Feed Manufacture}

Proximate analysis was conducted on base ingredients (corn, soybean meal, meat and bone meal, and DDGS) (Table 1), and incorporated into the feed formulation program ingredient matrix. A corn and soybean meal based diet (Table 2) was formulated based on average nutrient concentrations in the U.S. for broiler chickens in the finisher phase [8]. Corn and soybean meal were ground via hammer mill and augured into the mixer. Additional ingredients were added directly into a top access door of the mixer. All fat in the diet formulation was in the form of soybean oil. Three $136 \mathrm{~kg}$ batches of feed were mixed for 30 seconds and three $136 \mathrm{~kg}$ batches of feed were mixed for 10 minutes. Each batch, post mixing, was steam conditioned at $80^{\circ} \mathrm{C}$ for 10 seconds and extruded through a 4 x $38 \mathrm{~mm}$ pellet die using a 40-horsepower California Pellet Mill [9]. Pellet production rate was approximately $0.91 \mathrm{MT} / \mathrm{hr}$ and pellet conveyance post extrusion was accomplished with a series of flat bottom drag-chain conveyers and a bucket elevator. Pellets were cooled using a horizontal belt cooler and ambient air. During pelleting, samples were taken post extrusion from the pellet die as hot pellets and post conveyance and cooling as finished feed. Two or 10 samples were collected at equally spaced time intervals. 
Each sample was approximately $300 \mathrm{~g}$. Hot pellet samples were immediately cooled using ambient air and a fan for 12 minutes. Samples were pooled by placing samples into a general sample bag specific to sample location and time interval. Subsamples were obtained by blending pooled samples by hand or using a Humboldt sample splitting device [10]. Each subsample was approximately $300 \mathrm{~g}$.

\section{Sample Analysis}

Proximate analysis [11-14] and free supplemental amino acid analyses for DLmethionine and L-lysine $\mathrm{HCl}[15,16]$ were conducted on all subsamples by commercial laboratories $[17,18]$. All nutrient analysis followed proper AOAC methodologies [9-14] and moisture was adjusted to $15 \%$ to be similar to calculated moisture of the diet formulation (Table 2).

\section{Statistical Analysis}

A $2 \times 2 \times 2 \times 2$ factorial arrangement within a completely randomized design was used to explore the main effects and interactions of mix time, sampling location, sampling number, and blending technique. The experimental unit was a $300 \mathrm{~g}$ subsample of feed. Treatments were replicated three times. Analyses were completed using the GLM ANOVA procedure from the SAS Institute [19]. Means were considered significantly different at $\alpha \leq 0.05$.

\section{RESULTS AND DISCUSSION}

Results of the preliminary study that used a corn-salt mix and chloride ion analysis, suggested that a 10 minute mix time produced a superior mixer $\mathrm{CV}$ compared to a $30 \mathrm{sec}$ mix 
time $(P<0.05$, Table 3). Chloride ion analysis $\mathrm{CV}$ of complete corn and soybean meal based diets did not differ between mix times $(P>0.05)$, likely due to improper marker selection for the particular diet formulation. These results are in agreement with Clark et al. [3], who found crude protein, chloride ion, and phosphorus were not adequate predictors of mixer CV. Our assumption was that complete corn and soybean meal based diets mixed for 10 minutes produced a homogenous mixture of ingredients.

Calculated nutrient profiles from the feed formulation program determined from analyzed nutrients of ingredients in the formulation and diet inclusion were considered an accurate standard for comparison of subsample analytical nutrient values. In order to provide a concise presentation of results, only marginal means of the main effects and significant interactions were presented in Table 4. Crude fat and free supplemental DL-methionine were affected by mix time $(P<0.05)$. The 10 minute mix time produced crude fat and free supplemental DL-methionine that were lower and higher respectively compared to the $30 \mathrm{sec}$ mix time and agreed more with the calculated nutrient profile and diet formulation (Table 2). In addition, some of the pellets that were mixed for $30 \mathrm{sec}$ had a "fir tree" appearance. This characteristic of pellets has been linked to excessive lubrication at the mash and pellet die interface, and in the current study was likely associated with improper dispersion of soybean oil within the mix [20]. These results are in agreement with Creger [1], who utilized mix times ranging between 30 seconds and 20 minutes. Using the chloride ion analysis, the author concluded that diets were homogenous when mixed for at least five minutes. Another mixer uniformity study performed by McCoy et al. [2] utilized between five and 80 mixer revolutions, and resulted in mixer $\mathrm{CV}<10 \%$ when at least 35 revolutions were utilized. More recently, Clark et. al [3] suggested that mixer CV significantly 
decreased as mix time increased from 30 seconds to 5 minutes and samples were analyzed for free supplemental DL-methionine and L-lysine-HCl [3].

Free supplemental DL-methionine was also affected by sampling location $(P<0.05)$. Samples obtained at the pellet die were higher and agreed more with the diet formulation compared to finished feed samples obtained post conveyance and cooling. Total ash was affected by a sampling location and sampling technique interaction $(P<0.05)$. Samples collected at the pellet die were in closer agreement regardless of sample number; whereas, finished feed samples obtained post conveyance and cooling were affected more by sample number. These results were likely due to pellet attrition and ingredient separation from feed conveyance through the feed mill. Feed auguring or transportation via drag-chain has been shown to segregate feed particles, ingredients, and nutrients [21, 22]. Tang et al. [21] examined segregation patterns in hen houses that contained auger systems and drag-chain systems; the authors observed top-tobottom and side-to-side segregation within feed troughs. In top-to-bottom segregation, small, fine particles percolated to the bottom of the troughs while large, course particles remained at the top [21]. In side-to-side segregation, fine particles remained in the center of the trough while large particles separated to either side of the trough [21]. Moritz [22] observed that feed form segregation also occurs in commercial broiler house feed lines. Pelleted feed was shown to have improved conveyance to end feed pans whereas fines filtered at higher concentrations into feed pans more proximal to the in-house feed hopper.

Crude protein was affected by sampling technique $(P<0.05)$. Subsamples produced from two samples placed in a general sample bag provided a lower crude protein value and agreed more with the calculated nutrient profile than subsamples produced from 10 samples placed in a general sample bag (Tables 4 and 2). Intuitively, the number of samples collected 
should improve agreement to a calculated nutrient profile if the mix is not originally homogenous. However, crude protein was not affected by mix time i.e. lack of homogeneity. Therefore, crude protein variation in this study may be more associated with the marker being found in several ingredients and analytical error. Free supplemental L-lysine- $\mathrm{HCl}$ was not affected by any main effect or interaction in the current study. This result was in disagreement with Clark et al. [3], who observed a significant decrease in free supplemental L-lysine-HCl CV when mixing time was increased. The main effect, blending technique, did not influence nutrient analysis per se or interact with other main effects $(P>0.05$, Table 4$)$.

Chloride ion analysis in the preliminary study, and crude fat, free supplemental DLmethionine analysis, and physical appearance of pellets in the factorial study suggest that the 10 min mix time produced a homogenous mix of ingredients. Sampling location influenced nutrient analyses and agreement with diet formulation likely due to pellet attrition and ingredient segregation that occurs during conveyance through the feed mill. Sampling number had a more minor effect that was potentially confounded by marker selection and nutrient analysis and sample blending technique had no effect. We speculate that analysis of free supplemental DLmethionine from a sample obtained post extrusion from the pellet die may estimate diet homogeneity and indicate accordance to diet formulation. This sampling method has three major advantages: 1) free supplemental DL-methionine analysis of samples obtained at the pellet die would not be confounded by segregation due to feed conveyance; 2) free supplemental DLmethionine analysis comparison to diet formulation would be based on formulation inclusion and not nutrient analysis of several ingredients; and 3) free supplemental DL-methionine analysis would require a low number of samples ( 2 samples provided similar results to 10 samples in this study). 


\section{CONCLUSIONS AND APPLICATIONS}

1. Within the parameters of this study, pellets sampled at the pellet die and analyzed for free supplemental DL-methionine, standardized for percent moisture, may be the best metric for determining pelleted diet homogeneity and accordance to diet formulation.

\section{REFERENCES AND NOTES}

1. Creger, C. R. 1957. A study of distribution of micro-ingredients in mixed feeds. MS Thesis. Kansas State Univ., Manhattan.

2. McCoy, R. A., K. C. Behnke, J. D. Hancock, and R. R. McEllhiney. 1994. Effect of mixing uniformity on broiler chick performance. Poult. Sci. 73:443-451.

3. Clark, P. M., K. C. Behnke, and D. R. Poole. 2007. Effects of marker selection and mix time on the coefficient of variation (mix uniformity) of broiler feed. J. Appl. Poult. Res. 16:464-470.

4. Pfost, H. B., C, Deyoe, C. Stevens, and E. Morgan. 1966. Testing feed mixtures, mixers and related equipment. Feedstuffs 38:32-46.

5. Beaman, K. R., K. G. S. Lilly, C. K. Gehring, P. J. Turk, and J. S. Moritz. 2012. Influence of pelleting on the efficacy of an exogenous enzyme cocktail using broiler performance and metabolism. J. Appl. Poult. Res. 21:744-756.

6. MFP Vertical Mixer, Easy Automation Inc., Welcome, MN.

7. Chloride QuanTab Test Strips, 30-600 mg/L, Hach, Loveland, CO.

8. AgriStats Inc., Fort Wayne, IN; 2013.

9. Master Model Pellet Mill, California Pellet Mills Company, Crawfordsville, IN.

10. Humboldt Mfg. Co., Elgin, IL.

11. Official Methods of Analysis of AOAC Int., (2000) $17^{\text {th }}$ Ed., AOAC Int., Gaithersburg, MD, USA, Official Method 934.01.

12. Official Methods of Analysis of AOAC Int., (2000) $17^{\text {th }}$ Ed., AOAC Int., Gaithersburg, MD, USA, Official Method 942.05.

13. Official Methods of Analysis of AOAC Int., (2000) $17^{\text {th }}$ Ed., AOAC Int., Gaithersburg, MD, USA, Official Method 984.13. 
14. Official Methods of Analysis of AOAC Int., (2000) $17^{\text {th }}$ Ed., AOAC Int., Gaithersburg, MD, USA, Official Method 920.39.

15. Official Methods of Analysis of AOAC Int., (2000) $17^{\text {th }}$ Ed., AOAC Int., Gaithersburg, MD, USA, Official Method 692.09.

16. Official Methods of Analysis of AOAC Int., (2000) $17^{\text {th }}$ Ed., AOAC Int., Gaithersburg, MD, USA, Official Method 994.12.

17. New Jersey Feed Labs, Ewing Township, NJ.

18. The University of Missouri Agricultural Experiment Station Chemical Laboratories (ESCL), Columbia, MO.

19. SAS Institute. 2013. The SAS System for Windows 2000. Release 8.1. SAS Inst. Inc., Cary, NC.

20. Payne, J.D., Rattink, W., Smith, T., and Winowiski, T. 2001. Borregaard LignoTech. The Pelleting Handbook: A Guide for Production Staff in the Compound Feed Industry. 8.2.2:56-57.

21. Tang, P., P. H. Patterson, and V. M. Puri. 2006. Effect of feed segregation on the commercial hen and egg quality. J. Appl. Poult. Res. 15:564-573.

22. Moritz, J. 2013. Pellet quality performance tests: milling to bird performance. Proc. Arkansas Nutrition Conference. September 3-5. Rogers, AR. 
Table 1: Selected Analyzed Nutrients ${ }^{1}$ of Corn, Soybean Meal, Meat and Bone Meal, and Dried Distillers Grains and Solubles Used in the Diet Formulation.

\begin{tabular}{|c|c|c|c|c|}
\hline Ingredients & Moisture (\%) & Crude Protein (\%) & Crude Fat (\%) & Total Ash (\%) \\
\hline Corn & 15.40 & 6.22 & 3.05 & 1.03 \\
\hline Soybean Meal & 11.61 & 45.66 & 1.12 & 6.22 \\
\hline $\begin{array}{c}\text { Porcine Derived } \\
\text { M\&B Meal }\end{array}$ & 7.15 & 50.10 & 9.22 & 28.26 \\
\hline DDGS & 13.61 & 26.58 & 7.52 & 4.80 \\
\hline
\end{tabular}

${ }^{1}$ Values obtained from New Jersey Feed Labs (Ewing Township, NJ) 
Table 2: Ingredients and Calculated Nutrient Composition of the Broiler Finisher Diet

\begin{tabular}{|c|c|}
\hline Ingredient & Inclusion, \% \\
\hline Corn & 65.02 \\
\hline Soybean Meal (48\%) & 18.79 \\
\hline Meat and Bone Meal & 5.00 \\
\hline Dried Distillers Grains and Solubles & 5.00 \\
\hline Soybean Oil & 3.22 \\
\hline Dicalcium Phosphate & 1.24 \\
\hline Limestone & 0.68 \\
\hline Sodium Chloride & 0.28 \\
\hline Vitamin/Trace Mineral Premix ${ }^{1}$ & 0.25 \\
\hline DL-Methionine & 0.21 \\
\hline L-Lysine HCL & 0.19 \\
\hline L-Threonine & 0.05 \\
\hline Sodium Bicarbonate & 0.04 \\
\hline Ronozyme HiPhos ${ }^{2}$ & 0.03 \\
\hline \multicolumn{2}{|c|}{ Calculated Nutrients ${ }^{3}$} \\
\hline Metabolizable Energy $(\mathrm{kcal} / \mathrm{kg})^{4}$ & 2993 \\
\hline Moisture $(\%)$ & 15.00 \\
\hline Crude Protein $(\%)^{5}$ & 16.49 \\
\hline Crude Fat $(\%)$ & 6.11 \\
\hline Crude Fiber (\%) & 2.31 \\
\hline Total Ash (\%) & 5.54 \\
\hline Calcium (\%) & 1.03 \\
\hline Available Phosphorus $(\%)^{4}$ & 0.54 \\
\hline Sodium $(\%)$ & 0.19 \\
\hline Lysine (\%) & 0.87 \\
\hline Methionine + Cystine (\%) & 0.67 \\
\hline Threonine $(\%)$ & 0.57 \\
\hline
\end{tabular}

${ }^{1}$ Supplied per kg of diet: manganese, $0.02 \%$; zinc $0.02 \%$; iron, $0.01 \%$; copper, $0.0025 \%$; iodine, $0.0003 \%$; selenium, $0.00003 \%$; folic acid, $0.69 \mathrm{mg}$; choline, 386mg' riboflavin, $6.61 \mathrm{mg}$; biotin, $0.03 \mathrm{mg}$; vitamin B6, $1.38 \mathrm{mg}$; niacin, 27.56mg; pantothenic acid, $6.61 \mathrm{mg}$; thiamine, 2.20mg; manadione, 0.83mg; vitamin B12, 0.01mg; vitamin E, 16.53 IU; vitamin D3, 2133 ICU; vitamin A, 7716 IU

${ }^{2}$ DSM Nutritional Products- phytase.

${ }^{3}$ Values obtained from BRILL after nutrient specifications for corn, SBM, MBM, and DDGS were adjusted (Table 2) and after moisture was adjusted to $15 \%$.

${ }^{4}$ Metabolizable Energy and Available Phosphorus were based on Agristat values as suggested by M. Donohue. 2013. The Challenges in Feeding Broilers in Times of High and Volatile Feed Ingredient Costs: How to Cover the Costs?. 2013 Mid-Atlantic Nutrition Conference proceedings. Calcium values were adjusted to a 2.1:1 of Calcium to Available phosphorus.

${ }^{5}$ Digestible amino acids were based on ratios to lysine suggested by P. B. Tillman and W.A. Dozier. 2013. Current Amino Acid Considerations for Broilers: Requirements, Ratios, Economics. www.thepoultryfederation.com for $8-14$ day broilers. Digestible amino acid to digestible lysine ratios followed further recommendations of this communication (45 methionine, 70 threonine, 16 tryptophan, 105 arginine). 
Table 3: Coefficient of Variation of a Corn and Salt Formulation and a Complete Corn and Soybean Based Formulation Mixed for 30 Seconds and 10 Minutes.

\begin{tabular}{|c|c|c|}
\hline \multicolumn{3}{|c|}{ Corn-Salt ${ }^{1}$} \\
\hline & 30 Second Mix Time & 10 Minute Mix Time \\
\hline Mix 1 & $18.40 \%$ & $9.10 \%$ \\
\hline Mix 2 & $21.21 \%$ & $7.30 \%$ \\
\hline Mix 3 & $25.23 \%$ & $6.59 \%$ \\
\hline Mean Value & 21.61 & 7.66 \\
\hline $\begin{array}{c}\text { ANOVA Probability Value } \\
\text { Comparing } 30 \text { Second to } 10 \\
\text { Minute Mix Times }\end{array}$ & \multicolumn{2}{|c|}{0.0028} \\
\hline \multicolumn{3}{|c|}{ Complete Feed $^{2}$} \\
\hline Mix 1 & $10.85 \%$ & $9.57 \%$ \\
\hline Mix 2 & $8.63 \%$ & $8.39 \%$ \\
\hline Mix 3 & $15.38 \%$ & $11.28 \%$ \\
\hline Mean Value & 11.62 & 9.75 \\
\hline $\begin{array}{c}\text { ANOVA Probability Value } \\
\text { Comparing } 30 \text { Second to } 10 \\
\text { Minute Mix Times }\end{array}$ & \multicolumn{2}{|c|}{0.434} \\
\hline
\end{tabular}


Table 4: Main Effect Means and Probability Values for Main Effects and Interactions for Pelleted Subsample Nutrient Analyses.

\begin{tabular}{|c|c|c|c|c|c|c|c|c|}
\hline \multicolumn{4}{|c|}{$2 \times 2 \times 2 \times 2$ factorial arrangement of treatments } & \multicolumn{5}{|c|}{ Analyzed nutrients and feed ingredients } \\
\hline & & & & $\begin{array}{c}\text { Crude Protein } \\
(\%)\end{array}$ & $\begin{array}{c}\text { Crude Fat } \\
(\%)\end{array}$ & $\begin{array}{c}\text { Total Ash } \\
(\%)\end{array}$ & $\begin{array}{c}\text { Free supplemental DL- } \\
\text { methionine }(\%)\end{array}$ & $\begin{array}{c}\text { Free supplemental L-lysine } \\
\text { HCL }(\%)\end{array}$ \\
\hline \multicolumn{9}{|c|}{ Main Effect Means } \\
\hline \multicolumn{9}{|c|}{ Mix Time Means } \\
\hline 30 Seconds & ---- & ---- & ---- & 16.819 & 6.274 & 5.531 & 0.191 & 0.154 \\
\hline 10 Minutes & ---- & ---- & ---- & 16.828 & 6.112 & 5.668 & 0.197 & 0.155 \\
\hline \multicolumn{4}{|c|}{ Mix Time SEM ${ }^{1}$} & 0.122 & 0.036 & 0.050 & 0.002 & 0.002 \\
\hline \multicolumn{9}{|c|}{ Sampling Location Means } \\
\hline---- & Pellet Die $^{2}$ & ---- & ---- & 16.891 & 6.242 & 5.620 & 0.196 & 0.155 \\
\hline---- & Finished Feed $^{3}$ & ---- & ---- & 16.755 & 6.145 & 5.578 & 0.191 & 0.153 \\
\hline \multicolumn{4}{|c|}{ Sample Location SEM } & 0.122 & 0.036 & 0.050 & 0.002 & 0.002 \\
\hline \multicolumn{9}{|c|}{ Sampling Number Means } \\
\hline---- & ---- & 2 Samples & ---- & 16.628 & 6.233 & 5.647 & 0.195 & 0.155 \\
\hline---- & ---- & 10 Samples & ---- & 17.019 & 6.153 & 5.552 & 0.193 & 0.154 \\
\hline \multicolumn{4}{|c|}{ Sampling Number SEM } & 0.122 & 0.036 & 0.050 & 0.002 & 0.002 \\
\hline \multicolumn{9}{|c|}{ Blending Technique Means } \\
\hline---- & ---- & ---- & Hand Blending & 16.838 & 6.203 & 5.597 & 0.195 & 0.154 \\
\hline---- & ---- & $\begin{array}{c}--- \\
\end{array}$ & Splitting Device & 16.809 & 6.183 & 5.602 & 0.193 & 0.155 \\
\hline \multicolumn{4}{|c|}{ Blending Technique SEM } & 0.122 & 0.036 & 0.050 & 0.002 & 0.002 \\
\hline \multicolumn{9}{|c|}{ Probability Values for Mix Time x Sampling Location x Sampling Number x Blending Technique Factorial Arrangement } \\
\hline \multicolumn{4}{|c|}{ Mix Time } & 0.9603 & $\mathbf{0 . 0 0 3 0}$ & 0.0605 & 0.0195 & 0.5517 \\
\hline \multicolumn{4}{|c|}{ Sampling Location } & 0.4370 & 0.0623 & 0.5547 & 0.0408 & 0.3543 \\
\hline \multicolumn{4}{|c|}{ Sampling Number } & 0.0308 & 0.1231 & 0.1847 & 0.2747 & 0.6820 \\
\hline \multicolumn{4}{|c|}{ Blending Technique } & 0.8700 & 0.6970 & 0.9471 & 0.5519 & 0.6549 \\
\hline \multicolumn{4}{|c|}{ Sampling Location x Sampling Number } & 0.5302 & 0.8279 & 0.0313 & 0.7315 & 0.4802 \\
\hline
\end{tabular}

${ }^{1}$ Samples taken post-extrusion.

${ }^{2}$ Samples taken at the sack-off bin after bagging.

${ }^{3} \mathrm{SEM}=$ Standard error of the mean. 
CHAPTER 3: Efficacy of a novel protease provided to broiler chicks in diets that vary in composition and degree of processing

D.A. Reese and J.S. Moritz

Division of Animal and Nutritional Sciences, West Virginia University, Morgantown, West Virginia, 26506

Phone: 304-293-1911

Fax: 304-293-2232 
SUMMARY Exogenous enzymes added at the mixer should demonstrate activity post-pelleting and improve bird performance to justify use in the broiler industry. Past research has shown that diet substrate and the pelleting process can effect enzyme efficacy. The objective of the study was to evaluate the feeding value of a novel protease in unprocessed mash and pelleted diets that were composed of all vegetable protein or an inclusion of animal protein. Treatments were arranged in a $2 \times 2 \times 2$ factorial within a randomized complete block design. Protease inclusion was either 0 or $2 \%$. Diet composition was either all-vegetable protein or an $8 \%$ porcine meat and bone meal inclusion. Diets were fed as unprocessed mash or ground pellets that were steam conditioned at $70^{\circ} \mathrm{C}$ and extruded through a 4 x $38 \mathrm{~mm}$ pellet die. Pellets were ground prior to feeding to eliminate potentially confounding feed form effects. All diets were formulated to be $85 \%$ of crude protein and digestible amino acid recommendations for young broilers. In addition, two unprocessed mash diets representing the all-vegetable protein or $8 \%$ porcine meat and bone meal inclusion were formulated to be $100 \%$ of crude protein and digestible amino acid recommendations and were fed as controls. Dietary treatments were fed to nine replicate raised wire cages of eight straight-run Hubbard x Cobb broiler chicks for $21 \mathrm{~d}$. Protease activity was confirmed post pelleting and expressed in tyrosine releasing units that compare the absorbance of tyrosine liberated by protease digested casein to a standard curve generated by a tyrosine dilution. Protease and Degree of Processing interacted to effect chick weight gain and feed conversion ratio $(\mathrm{FCR})(\mathrm{P}<0.05)$. Protease applied to pelleted diets improved $21 \mathrm{~d}$ weight gain by $57 \mathrm{~g}$ and decreased $21 \mathrm{~d}$ FCR by 0.07 . Similar improvements were not observed in unprocessed mash diets. Linear contrasts clarified that protease applied to pelleted diets was most beneficial for all vegetable protein compositions $(\mathrm{P}<0.05)$. Diet Composition and Degree of Processing interacted to effect FCR $(\mathrm{P}<0.05)$. Meat and bone meal inclusion increased feed 
conversion ratio in unprocessed mash diets but not pelleted diets. Protease efficacy was influenced by diet composition and degree of processing.

Keywords: Protease, Activity, Pelleting, Broiler, Performance 


\section{DESCRIPTION OF PROBLEM}

Feed and feed manufacture account for the largest cost of broiler production. Profitability for the integrator and the grower can be dependent on multiple feed variables, such as ingredient cost, pelleting cost, and nutrient availability of ingredients post manufacture [1]. Nutritionists may be able to improve nutrient availability or decrease diet costs by incorporating exogenous enzymes in the formulation, such as phytase, xylanase, amylase, glucanase, or protease. Exogenous enzymes added at the mixer should demonstrate activity post-pelleting to show that conditions of heat, moisture, and pressure have not diminished the products potential to function. However, in vitro testing of enzyme activity post-pelleting per se may not predict efficacy in the animal [2-4]. Loop and coauthors [6] found that in vitro nutrient releasing assays for phytase do not always predict broiler chick performance benefits.

Sigma-Aldrich developed a non-specific activity assay for proteases [5]. In this particular assay, casein acts as the substrate for protease and liberation of the amino acid tyrosine is quantified through readings from a spectrophotometer. The readings express activity in tyrosine releasing units per gram (TU/g) based on a calculation comparing feed samples with and without protease. Research has also suggested that enzyme inactivation can occur due to frictional heat at the mash-die interface [7-9]. Gehring et al. [8] examined thermal stability of an exogenous enzyme cocktail (EEC) when added to diets containing either 1 or $4 \%$ mixer added fat (MAF). The authors concluded that diets containing an EEC with 4\% MAF decreased relative electrical energy usage of the pellet mill (PREEU), improved live weight gain, and decreased FCR. Another experiment performed by Corey et al. [9] demonstrated that increasing MAF to $3 \%$ in a diet containing $0.5 \%$ calcium lignosulfonate decreased FCR and improved true amino acid digestibility (TAAD). These findings suggest that increasing MAF lubricates the pellet die, 
decreases frictional force, improves nutrient digestibility, and may enable improved exogenous enzyme survivability [8, 9].

Two experiments were conducted utilizing a novel plant based protease granulated with zeolite and designed to be added to feed at the mixer [10]. The objective of the first experiment was to determine protease activity using a tyrosine releasing laboratory assay and develop an appropriate diet formulation and conditions of feed manufacture to subsequently be used for broiler feeding. The objective of the second experiment was to evaluate the feeding effects of the protease in unprocessed mash and pelleted diets that were composed of all vegetable protein or an $8 \%$ inclusion of porcine meat and bone on broiler performance.

\section{MATERIALS AND METHODS}

\section{Experiment 1}

Protease Assay

A feed manufacture experiment was performed to determine proper conditioning temperature and protease inclusion for broiler diets. In vitro general protease activity assays were utilized and based on methods developed by Sigma-Aldrich [5]. Assays were performed on the pure protease, mash, and pelleted feed samples with and without protease. Either $0.1 \mathrm{~g}$ pure protease or $2.0 \mathrm{~g}$ feed samples were weighed and placed into $250 \mathrm{~mL}$ Erlenmeyer flasks. One hundred $\mathrm{mL}$ of an assay buffer (sodium phosphate, EDTA, and Cysteine- $\mathrm{HCl}$ solution, $\mathrm{pH}$ 6.0) was added to each flask and mixed for 10 minutes. During sample mixing, five $\mathrm{mL}$ of a casein solution was added to round bottom tubes (two for each protease/feed sample), covered with Parafilm, and placed in a $40^{\circ} \mathrm{C}$ water bath for 10 minutes. Tubes were removed from the water 
bath, two mL from Erlenmeyer flasks were added, and tubes were again covered with Parafilm and placed back into the water bath for 60 minutes. Once again tubes were removed from the water bath, $3 \mathrm{~mL} \mathrm{30 \%} \mathrm{trichloroacetic} \mathrm{acid} \mathrm{was} \mathrm{added} \mathrm{to} \mathrm{each} \mathrm{tube,} \mathrm{and} \mathrm{tubes} \mathrm{were} \mathrm{covered} \mathrm{with}$ Parafilm and placed back into the water bath for 30 minutes. Tubes were removed and centrifuged for 5 minutes at 13,000 rpm. Supernatant was poured into a $15 \mathrm{~mL}$ tube and read on a spectrophotometer at $280^{\circ}$ absorbance (Abs.). Readings were included in the following equation to calculate tyrosine releasing units per gram:

$$
\text { TU/g Feed }=\frac{((\text { Sample Abs. }- \text { Blank Abs. }) \times \text { Standard Curve Slope })}{60} \times \frac{100 \mathrm{~mL}}{\mathrm{Wt} .} \frac{10 \mathrm{~mL}}{2 \mathrm{~mL}}
$$

Feed samples that contained protease were then corrected to eliminate error associated with tyrosine release in feed without protease.

Corrected TU/g Feed $=$ TU/g Diet Containing Protease - TU/g Diet Containing No Protease

Enzyme activity per se TU/g was then calculated using the following calculation:

TU/g Enz $=\underline{(\text { TU/g Diet Containing Protease }- \text { TU/g Diet Containing No Protease })}$

$\%$ Protease Inclusion

\section{Feed Manufacture}

Based on general inclusions of commercially available exogenous enzymes, a corn and soybean meal based diet was formulated to contain $0.03 \%$ protease and $1.82 \%$ MAF. Feed was manufactured using a $40 \mathrm{HP}$ California Pellet Mill [11] and steam conditioned at 50, 60, or $70^{\circ} \mathrm{C}$ for ten seconds before passing through a 4 x $38 \mathrm{~mm}$ pellet die. Ten mash samples per treatment were taken from the mixer [12] and three hot pellet samples per treatment were taken postextrusion from the pellet die. This sampling area was previously found to provide the best representation of calculated nutrients and ingredient inclusion of diets [13]. Hot pellet samples 
were cooled using ambient air and a fan for 12 minutes. Samples were analyzed before and after pelleting to determine thermal stability of the protease. Analysis of TU/g could not differentiate between samples with or without protease likely due to protease inclusion being too low for the sensitivity of the activity assay within a complete feed. Diets were then reformulated to contain either $1,2,5$, or $10 \%$ protease and activity assays were conducted on unprocessed mash samples. A diet containing $2 \%$ protease and $1.82 \%$ MAF was formulated and steam conditioned at 50, 60, 70 , and $80^{\circ} \mathrm{C}$ for ten seconds and extruded through a 4 x $38 \mathrm{~mm}$ pellet die. Subsequently, a diet containing $2 \%$ protease and $4.25 \%$ MAF was formulated and steam conditioned at 50, 60, 70, and $80^{\circ} \mathrm{C}$ for ten seconds and extruded through a 4 x $38 \mathrm{~mm}$ pellet die. Samples were collected and analyzed as previously described. These experiments were preliminary and pelleted batches were not replicated. Therefore these data should be viewed as descriptive.

\section{Experiment 2}

\section{Feed Manufacture}

Corn and soybean meal based diets were formulated to contain either all vegetable protein or an $8 \%$ inclusion of porcine derived meat and bone meal (M\&B) (Table 1). Protease inclusion was either 0 or $2 \%$. Diets were fed as unprocessed mash or ground pellets that were steam conditioned at $70^{\circ} \mathrm{C}$ for 10 seconds and extruded through a 4 x $38 \mathrm{~mm}$ pellet die. Pellets were ground prior to feeding to eliminate potentially confounding feed form effects. All diets were formulated to be $85 \%$ of crude protein and digestible amino acid recommendations for young broilers [14]. In addition, two unprocessed mash diets representing the all vegetable

protein or an $8 \%$ inclusion of porcine meat and bone meal were formulated to be $100 \%$ of crude protein and digestible amino acid recommendations and were fed as controls. 
All feed was manufactured at the West Virginia University Pilot Feed Mill. Each experimental diet was batched and split into two, $113 \mathrm{~kg}$ allotments. One allotment of each diet was fed as unprocessed mash and one allotment was conditioned and pelleted. Cooled pellets were passed through a roller mill to create a feed particle size similar to that of a mash diet to eliminate potentially confounding feed form effects (table 4). Pelleted diet samples were taken post-extrusion from the pellet die and immediately cooled using ambient air and a fan for 12 minutes. Samples were used to determine particle size [14] (Table 4) and protease activity post pelleting (Table 5).

\section{Live Bird Performance}

A total of 720 Hubbard x Cobb 500 straight-run broiler chicks obtained from a commercial hatchery [16] were reared in raised wire cages $(30.48 \times 50.80 \mathrm{~cm})$ in two crossventilated, negative-pressure rooms that contained 48 cages each. Each dietary treatment was fed to nine replicate pens containing eight broilers/cage. The experimental unit was considered one cage. Blocking was conducted based on adjacent cage area within the rooms. Each cage contained nipple drinkers and an external feed trough. Mortalities from d 1-3 were replaced. Birds were weighed as an experimental unit on $\mathrm{d} 1$ and 21 . On d 18, 0.2\% titanium dioxide was added to the feed via top-dress. On d 21, five randomly selected birds/cage were euthanized via cervical dislocation, weighed, and the lower ileum was excised and gently flushed to remove digesta. Measured variables included feed intake per bird (FI), live weight gain per bird (LWG), ending bird weight (EBW), and mortality corrected FCR. All birds were reared using environmental recommendations obtained from Cobb-Vantress [17], and approved protocols 
were established by the West Virginia University Animal Care and Use Committee [ACUC 150408].

\section{Statistical Analysis}

A $2 \times 2 \times 2$ factorial arrangement in a randomized complete block design was utilized to explore the main effects and interactions of diet substrate, feed processing, and protease inclusion. The experimental unit was one pen containing eight broilers. Blocking criterion consisted of cage location in the rooms. Analyses were completed using the GLM ANOVA procedure from the SAS Institute. When main effects significantly interacted, treatments were compared using Fisher's LSD multiple comparison test. Linear contrasts were performed to clarify main effect interactions. Means were considered significantly different at $\alpha \leq 0.05$.

\section{RESULTS AND DISCUSSION}

\section{Experiment 1}

Feed samples that contained $0.03 \%$ protease were indistinguishable from feed samples that did not contain protease in terms of TU/g (data not shown). Therefore, diets were reformulated to contain either $1,2,5$, or $10 \%$, protease and activity assays were conducted on unprocessed mash samples (Table 2). The $2 \%$ protease level was chosen for continued testing in conditioning and pelleting survivability due those formulations generating repeatable and relatively high in vitro activity. A diet containing $2 \%$ protease and $1.82 \%$ MAF was then steam conditioned at $50,60,70$, and $80^{\circ} \mathrm{C}$. However, protease assays demonstrated low activity (data 
not shown). Hot pellet temperature (HPT), generated during pelleting of these diets was elevated by approximately $20^{\circ} \mathrm{C}$ for all conditioning temperatures. Suspecting that MAF was too low for enzyme survivability, a new diet was formulated containing $2 \%$ protease and $4.25 \%$ MAF. Protease activity was retained for each conditioning temperature and decreased as conditioning temperature increased (Table 3). A similar result was found by Gehring et al. [8], who tested thermal stability of an EEC when added to diets containing either 1 or $4 \%$ MAF. The authors found that diets containing the EEC with $4 \%$ MAF decreased relative electrical energy usage of the pellet mill (PREEU), improved live weight gain, and decreased FCR of subsequently fed chicks. These results were likely associated with increased lubrication at the mash-die interface and decreased frictional heat generation. A conditioning temperature of $70^{\circ} \mathrm{C}$ was selected for further testing in Experiment 2 due to that temperature being closer to commercial feed manufacture practices, while maintaining activity that we speculated could still produce an in vivo response.

\section{Experiment 2}

Descriptive results of the physical characteristic tests of pelleted feed are found in Table 4. Pellet durability among treatments was not remarkable and particle size analysis demonstrated that pellet grinding had the effect of producing a similar particle sized feed as unprocessed mash treatments.

Protease recovery data is shown in table 5. Unprocessed mash diets that contained $8 \%$ porcine meat and bone meal (M\&B) numerically decreased protease activity compared to allvegetable diets. Furthermore, no activity was detected for the protease when applied to diets that contained $8 \% \mathrm{M} \& \mathrm{~B}$ and were pelleted. In regard to live performance, protease and degree of 
processing interacted to effect chick weight gain and feed conversion ratio $(\mathrm{FCR})(\mathrm{P}<0.05)$.

Protease applied to pelleted diets improved $21 \mathrm{~d}$ weight gain by $57 \mathrm{~g}$ and decreased $21 \mathrm{~d}$ FCR by 0.07. Similar improvements were not observed in unprocessed mash diets. Linear contrasts clarified that protease applied to pelleted diets was most beneficial for all vegetable protein compositions $(\mathrm{P}<0.05)$. The particular protease likely has a greater effect on vegetable proteins compared to animal proteins. The diet containing $8 \%$ porcine meat and bone meal had a reduced soybean meal content of approximately $30 \%$ compared to the all-vegetable protein diet. The reduced protease activity due to the conditioning and pelleting process likely further reduced enzyme efficacy in the $8 \%$ porcine meat and bone meal diets. Evans and Moritz [22] observed similar results when broilers were fed diets that contained either vegetable or animal protein and a protease. Birds that were fed all vegetable protein diets with protease had greater amino acid digestibility, increased BWG, and improved FCR compared to birds that were fed diets containing animal protein with protease [22]. In regard to improved protease efficacy with diets that were pelleted, perhaps the soybean meal substrate underwent conformational changes due to pelleting that improved protease accessibility. Similar results have been observed for the effect of glucanase and pelleted barley based diets [23].

Diet Composition and Degree of Processing interacted to effect FCR $(\mathrm{P}<0.05)$. Meat and bone meal inclusion increased feed conversion ratio in unprocessed mash diets but not pelleted diets. The conditioning and pelleting process may have improved digestibility of the porcine meat and bone meal. Past research has shown benefits of protease inclusion in broiler diets. Keratinase added to corn and soybean meal based broiler diets formulated to be $93 \%$ of NRC requirement for crude protein has been shown to increase bird ending body weight up to $32 \mathrm{~g}$ [18]. Stark et al. [19] also utilized keratinase in corn and soybean meal based broiler diets and 
performed enzymatic recovery assays. Despite decreased activity retention in pelleted diets (66\%) compared to mash diets (93\%), inclusion of keratinase in pelleted diets increased weight gain (798 to $838 \mathrm{~g}$ ) and improved FCR (1.57 to 1.55$)$ relative to diets without keratinase. The conditions of the current study suggest that protease efficacy was influenced by diet composition and degree of processing.

\section{CONCLUSIONS AND APPLICATIONS}

1. In vitro protease activity was demonstrated for all diets through tyrosine releasing units except for pelleted diets containing $8 \%$ porcine derived meat and bone meal.

2. Feed Processing $x$ Protease Inclusion interactions showed improvement in broiler EBW, LWG, and FCR for broilers that were fed diets that were pelleted and contained protease.

3. Performance improvements were more prominent in diets containing all vegetable protein.

\section{REFERENCES AND NOTES}

1. Beaman, K. R., K. G. S. Lilly, C. K. Gehring, P. J. Turk, and J. S. Moritz. 2012. Influence of pelleting on the efficacy of an exogenous enzyme cocktail using broiler performance and metabolism. J. Appl. Poult. Res. 21:744-756.

2. Malathi, V. and G. Devegowda. 2001. In vitro evaluation on nonstarch polysaccharide digestibility of feed ingredients by enzymes. Poult. Sci. 80:302-305.

3. Freitas, D. M., S. L. Vieira, C. R. Angel, A. Favero, and A. Maiorka. 2011. Performance and nutrient utilization of broilers fed diets supplemented with a novel mono-component protease. J. Appl. Poult. Res. 20:322-334.

4. Loop, S. A., K. G. S. Lilly, L. K. Shires, C. K. Gehring, K. R. Beaman, M. E. Persia, and J. S. Moritz. 2012. The phytase analytical activity of pelleted diets may not adequately describe efficacy in the bird. J. Appl. Poult. Res. 21:492-501.

5. Cupp-Enyard, C. 2008. Sigma's non-specific protease activity assay - casein as a substrate. J. Vis. Exp. 19:889. 
6. Angel, C. R., W. Saylor, S. L. Vieira, and N. Ward. 2011. Effects of a monocomponent protease on performance and protein utilization in 7- to 22-day-old broiler chickens. Poult. Sci. 90:2281-2286.

7. Lamp, A. E., A. M. Evans, and J. S. Moritz. 2015. The effects of pelleting and glucanase supplementation in hulled barley based diets on feed manufacture, broiler performance, and digesta viscosity. J. Appl. Poult. Res. 24:295-303.

8. Gehring, C. K., K. G. S. Lilly, L. K. Shires, K. R. Beaman, S. A. Loop, and J. S. Moritz. 2011. Increasing mixer-added fat reduces the electrical energy required for pelleting and improves exogenous enzyme efficacy for broilers. J. Appl. Poult. Res. 20:75-89.

9. Corey, A. M., K. G. S. Wamsley, T. S. Winowiski, and J. S. Moritz. 2014. Effects of calcium lignosulfonate, mixer-added fat, and feed form on feed manufacture and broiler performance. J. Appl. Poult. Res. 23:418-428.

10. Kiwi Enzyme, LLC. Auckland, New Zealand.

11. Master Model Pellet Mill, California Pellet Mills Company, Crawfordsville, IN.

12. MFP Vertical Mixer, Easy Automation Inc., Welcome, MN.

13. Reese, D. A., K. L. Foltz, and J. S. Moritz. 2015. Effect of feed mixing and sampling variables on nutrient analysis. Poult. Sci. (Accepted Abstract (101)).

14. Tillman, P. B. and W. A. Dozier, III. 2013. Update on Amino Acids for Broilers. The Poultry Federation.

15. RO-Tap RX-29, W.S. Tyler, Mentor, OH.

16. Pilgrim's Pride Hatchery, Moorefield, WV.

17. Cobb-Vantress, Siloam Springs, AR. 2008. Cobb 500 Broiler Performance and Nutrition Supplement.

18. Odetallah, N. H., J. J. Wang, J. D. Garlich, and J. C. H. Shih. 2003. Keratinase in starter diets improves growth of broiler chicks. Poult. Sci. 82:664-670.

19. Stark, C. R., B. E. Spencer, J. C. H. Shih, C. G. Chewning, and J. J. Wang. 2009. Evaluation of keratinase stability in pelleted broiler diets. J. Appl. Poult. Res. 18:30-33.

20. Loop, S. A., K. G. S. Lilly, L. K. Shires, C. K. Gehring, K. R. Beaman, M. E. Persia, and J. S. Moritz. 2012. The phytase analytical activity of pelleted diets may not adequately describe efficacy in the bird. J. Appl. Poult. Res. 21:492-501. 
21. Corey, A. M., K. G. S. Wamsley, T. S. Winowiski, and J. S. Moritz. 2014. Effects of calcium lignosulfonate, mixer-added fat, and feed form on feed manufacture and broiler performance. J. Appl. Poult. Res. 23:418-428.

22. Evans, A. M. and J. S. Moritz. 2014. Effects of dietary enzyme supplementation on nutrient digestibility and growth performance of chicks fed diets with high amounts of meat and bone meal. Poult. Sci. (Accepted Abstract (60)).

23. Lamp, A. E., A. M. Evans, and J. S. Moritz. 2015. The effects of pelleting and glucanase supplementation in hulled barley based diets on feed manufacture, broiler performance, and digesta viscosity. J. Appl. Poult. Res. 24:295-303. 
Table 1: Ingredients and Calculated Nutrient Composition of Broiler Starter Diets

\begin{tabular}{|c|c|c|c|c|}
\hline Ingredient & $\begin{array}{c}\text { Inclusion }(\%) \\
\text { Vegetable Protein, } \\
\text { 85\% Digestible } \mathbf{A A}^{1}\end{array}$ & $\begin{array}{c}\text { Inclusion (\%) } \\
\text { M\&B Meal, 85\% } \\
\text { Digestible AA } \mathbf{A A}^{2}\end{array}$ & $\begin{array}{c}\text { Inclusion (\%) } \\
\text { Vegetable Protein, } \\
100 \% \text { Digestible } \text { AA }^{3}\end{array}$ & $\begin{array}{c}\text { Inclusion (\%) } \\
\text { M\&B Meal, 100\% } \\
\text { Digestible } \mathbf{A A}^{\mathbf{4}}\end{array}$ \\
\hline Corn & 54.21 & 59.31 & 44.54 & 49.60 \\
\hline Soybean Meal & 34.94 & 25.53 & 43.47 & 34.19 \\
\hline Porcine Meat \& Bone Meal & - & 8.00 & - & 8.00 \\
\hline Soybean Oil & 4.25 & 3.23 & 5.33 & 4.30 \\
\hline Dicalcium Phosphate & 2.09 & 0.34 & 2.03 & 0.28 \\
\hline Sand or Protease & 2.00 & 2.00 & 2.00 & 2.00 \\
\hline Limestone & 1.48 & 0.50 & 1.46 & 0.48 \\
\hline DL-Methionine & 0.30 & 0.32 & 0.41 & 0.40 \\
\hline Salt & 0.29 & 0.15 & 0.30 & 0.15 \\
\hline Poultry Vitamin Premix ${ }^{5}$ & 0.25 & 0.25 & 0.25 & 0.25 \\
\hline Sodium Bicarbonate & 0.15 & 0.15 & 0.15 & 0.15 \\
\hline Lysine & - & 0.12 & - & 0.09 \\
\hline L-Threonine & 0.04 & 0.10 & 0.06 & 0.11 \\
\hline Total & 100 & 100 & 100 & 100 \\
\hline \multicolumn{5}{|c|}{ Calculated Nutrients } \\
\hline Metabolizable Energy $(\mathrm{Kcal} / \mathrm{kg})^{6}$ & $2,999.64$ & $2,999.64$ & $2,999.64$ & $2,999.64$ \\
\hline Crude Protein $^{7}$ & 20.40 & 20.40 & 24.00 & 24.00 \\
\hline Calcium & 1.08 & 1.08 & 1.08 & 1.08 \\
\hline Available Phosphorus $^{6}$ & 0.51 & 0.51 & 0.51 & 0.51 \\
\hline Sodium & 0.17 & 0.17 & 0.17 & 0.17 \\
\hline Digestible Lysine & 1.02 & 1.02 & 1.22 & 1.20 \\
\hline Digestible Methionine & 0.43 & 0.46 & 0.52 & 0.53 \\
\hline Digestible Methionine + Cystine & 0.93 & 0.93 & 1.09 & 1.06 \\
\hline Digestible Threonine & 0.71 & 0.71 & 0.84 & 0.84 \\
\hline
\end{tabular}

${ }^{1}$ Diet formulation utilizing vegetable protein and containing $85 \%$ digestible crude protein and amino acids. Formulation was used for the following four experimental diets: Diet 1- Mash, Sand. Diet 2- Ground Pellet, Sand. Diet 3- Mash, Actinidin. Diet 4Ground Pellet, Actinidin.

${ }^{2}$ Diet formulation utilizing $8 \%$ porcine meat and bone meal and $85 \%$ digestible crude protein and amino acids. Formulation was used for the following four experimental diets: Diet 5- Mash, Sand. Diet 6- Ground Pellet, Sand. Diet 7- Mash, Actinidin. Diet 8Ground Pellet, Actinidin.

${ }^{3}$ Diet formulation utilizing vegetable protein and containing $100 \%$ digestible crude protein and amino acids. Formulation was used for the following control diet: Diet 9- Mash, Sand.

${ }^{4}$ Diet formulation utilizing $8 \%$ porcine meat and bone meal and $100 \%$ digestible crude protein and amino acids. Formulation was used for the following control diet: Diet 10- Mash, Sand.

${ }^{5}$ Supplied per kilogram of diet: $0.02 \%$ manganese; $0.02 \%$ zinc; $0.01 \%$ iron; $0.0025 \%$ copper; $0.0003 \%$ iodine; $0.00003 \%$ selenium; $0.69 \mathrm{mg}$ of folic acid; $386 \mathrm{mg}$ of choline; $6.61 \mathrm{mg}$ of riboflavin; $0.03 \mathrm{mg}$ of biotin; $1.38 \mathrm{mg}$ of vitamin B6; $27.56 \mathrm{mg}$ of niacin; $6.61 \mathrm{mg}$ of pantothenic acid; $2.20 \mathrm{mg}$ of thiamine; $0.83 \mathrm{mg}$ of menadione; $0.01 \mathrm{mg}$ of vitamin B12; $16.53 \mathrm{IU}$ of vitamin E; 2,133 ICU of vitamin D3; and 7,716 IU of vitamin A.

${ }^{6}$ Metabolizable Energy and Available Phosphorus were based on Agristat values as suggested by M. Donohue. 2013. The Challenges in Feeding Broilers in Times of High and Volatile Feed Ingredient Costs: How to Cover the Costs?. 2013 MidAtlantic Nutrition Conference proceedings. Calcium values were adjusted to a 2.1:1 of Calcium to Available phosphorus. ${ }^{7}$ Digestible amino acid reductions (15\%) were based on digestible amino acid ratios to lysine suggested by P. B. Tillman and W.A. Dozier. 2013. Current Amino Acid Considerations for Broilers: Requirements, Ratios, Economics. www.thepoultryfederation.com for $8-14$ day broilers. Digestible amino acid to digestible lysine ratios followed further recommendations of this communication (45 methionine, 70 threonine, 16 tryptophan, 105 arginine). 
Table 2: Determination of Dosage of Protease to be Utilized in Broiler Diets Using Unprocessed Mash ${ }^{1}$

\begin{tabular}{|c|c|c|c|}
\hline Sample & TU/g Feed $^{2}$ & Corrected $^{3}(\mathrm{TU} / \mathrm{g})$ & TU/g Enz. ${ }^{4}$ \\
\hline Pure Protease & - & - & 6,890 \\
\hline Feed $+0 \%$ Protease & 217.93 & - & - \\
\hline Feed $+1 \%$ Protease & 254.63 & 36.70 & 3,670 \\
\hline Feed $+0 \%$ Protease & 198.21 & - & - \\
\hline Feed $+2 \%$ Protease & 287.49 & 89.28 & 4,464 \\
\hline Feed $+0 \%$ Protease & 266.48 & - & - \\
\hline Feed $+5 \%$ Protease & 417.29 & 150.81 & 3,016 \\
\hline Feed $+0 \%$ Protease & 191.33 & - & - \\
\hline Feed $+10 \%$ Protease & 613.65 & 422.32 & 4,223 \\
\hline
\end{tabular}

${ }^{1}$ Corn and soybean meal based diet with $1.82 \%$ MAF.

${ }^{2}$ Tyrosine Releasing Units/g of tyrosine liberated from the feed using the TU Assay $=(($ Sample Abs. - Blank Abs. $) \mathrm{x}$ Standard Curve Slope) $/ 60$ x $100 \mathrm{~mL} / \mathrm{Wt}$. $\times 10 \mathrm{~mL} / 2 \mathrm{~mL}$

${ }^{3}$ Removal of error from tyrosine present in feed per se $=\mathrm{TU} / \mathrm{g}$ Diet Containing Protease $-\mathrm{TU} / \mathrm{g}$ Diet Containing No Protease ${ }^{4}$ Tyrosine Releasing Units per gram of enzyme $=(\mathrm{TU} / \mathrm{g}$ Diet Containing Protease $-\mathrm{TU} / \mathrm{g}$ Diet Containing No Protease $) / \%$ Protease Inclusion

Table 3: Determination of Conditioning Temperature for $2 \%$ Inclusion of Protease in an All Vegetable Protein Diet ${ }^{1}$

\begin{tabular}{|c|c|c|c|c|}
\hline Feed Processing & TU/g Feed ${ }^{2}$ & Corrected $^{3}(\mathrm{TU} / \mathrm{g})$ & TU/g Enz. ${ }^{4}$ & Retention $(\%)^{5}$ \\
\hline $2 \%$ Inclusion Mash 6 & 227.06 & 53.94 & 2697.36 & - \\
\hline $50^{\circ} \mathrm{C}$ & 281.32 & 54.26 & 2712.90 & $100 \%$ \\
\hline $60^{\circ} \mathrm{C}$ & 269.31 & 42.25 & 2112.35 & $78 \%$ \\
\hline $70^{\circ} \mathrm{C}$ & 250.14 & 23.08 & 1153.72 & $43 \%$ \\
\hline $80^{\circ} \mathrm{C}$ & 241.22 & 14.16 & 707.59 & $26 \%$ \\
\hline
\end{tabular}

${ }^{1}$ Pelleted corn and soybean meal based diets with $4.25 \%$ MAF were steam conditioned for 10 seconds.

${ }^{2}$ Tyrosine Releasing Units/g of tyrosine liberated from the feed using the TU Assay $=(($ Sample Abs. - Blank Abs. $) \times$ Standard Curve Slope)/60 x 100mL/Wt. x $10 \mathrm{~mL} / 2 \mathrm{~mL}$

${ }^{3}$ Removal of error from tyrosine present in feed per se $=$ TU/g Diet Containing Protease - TU/g Diet Containing No Protease ${ }^{4}$ Tyrosine Releasing Units/g of tyrosine liberated from the protease alone $=(\mathrm{TU} / \mathrm{g}$ Diet Containing Protease $-\mathrm{TU} / \mathrm{g}$ Diet Containing No Protease) / \% Protease Inclusion

${ }^{5}$ Amount of enzymatic activity retained in pelleted diets.

${ }^{6} 2 \%$ inclusion of protease in unprocessed mash samples. 
Table 4: Descriptive Feed Manufacture Data of Experiment 2

\begin{tabular}{|c|c|c|c|c|c|c|}
\hline Diet Substrate & Feed Processing & $\begin{array}{l}\text { Novel Protease } \\
\text { Inclusion }\end{array}$ & PDI $(\%)^{1}$ & $\operatorname{MPDI}(\%)^{2}$ & $\begin{array}{c}\text { New Holman } \\
(\%)^{3}\end{array}$ & $\begin{array}{c}\text { Particle Size } \\
\qquad(\mu)^{4}\end{array}$ \\
\hline \multirow[t]{5}{*}{ All Vegetable } & \multirow[t]{2}{*}{ Ground Pellet } & No & 76.81 & 65.77 & 48.26 & 995.51 \\
\hline & & Yes & 79.80 & 72.47 & 52.81 & 937.89 \\
\hline & \multirow[t]{2}{*}{ Unprocessed Mash } & No & - & - & - & 955.78 \\
\hline & & Yes & - & - & - & 985.50 \\
\hline & Unprocessed Mash PC & No & - & - & - & 957.56 \\
\hline \multirow{5}{*}{$\begin{array}{l}\text { Meat and Bone } \\
\text { Meal Inclusion }\end{array}$} & \multirow{2}{*}{ Ground Pellet } & No & 71.93 & 63.37 & 38.92 & 972.78 \\
\hline & & Yes & 74.59 & 65.70 & 40.92 & 964.25 \\
\hline & \multirow[t]{2}{*}{ Unprocessed Mash } & No & - & - & - & 941.12 \\
\hline & & Yes & - & - & - & 941.07 \\
\hline & Unprocessed Mash PC & No & - & - & - & 947.77 \\
\hline
\end{tabular}

Pellet durability index obtained using a pfost tumbling box.

${ }^{2}$ Modified pellet durability index obtained using a pfost tumbling box and adding five hex nuts to the sample.

${ }^{3}$ Pellet durability index obtained using a New Holman Pellet Tester.

${ }^{4}$ Size of feed particles obtained using a ro-tap sieve shaker. 
Table 5: Protease Activity Obtained From Experiment 2 Using the Tyrosine Releasing Unit Assay

\begin{tabular}{|c|c|c|c|c|c|}
\hline Diet Substrate & Feed Processing & Novel Protease Inclusion & $\begin{array}{c}\text { Tyrosine Releasing } \\
\text { Units/g Feed }^{1}\end{array}$ & $\begin{array}{c}\text { Corrected }^{2} \\
\text { (Tyrosine Releasing } \\
\text { Units/g) }\end{array}$ & $\begin{array}{c}\text { Tyrosine Releasing } \\
\text { Units/g Enzyme }^{3}\end{array}$ \\
\hline \multirow{5}{*}{ All Vegetable } & \multirow{2}{*}{ Ground Pellet } & No & 302.51 & - & - \\
\hline & & Yes & 408.31 & 75.62 & 3780.82 \\
\hline & \multirow{2}{*}{ Unprocessed Mash } & No & 312.24 & - & - \\
\hline & & Yes & 420.62 & 87.96 & 4398.07 \\
\hline & Unprocessed Mash PC & No & 332.69 & - & - \\
\hline \multirow{5}{*}{$\begin{array}{l}\text { Meat and Bone Meal } \\
\text { Inclusion }\end{array}$} & \multirow{2}{*}{ Ground Pellet } & No & 434.28 & - & - \\
\hline & & Yes & 415.14 & -12.33 & -616.66 \\
\hline & \multirow{2}{*}{ Unprocessed Mash } & No & 370.34 & - & - \\
\hline & & Yes & 481.35 & 53.89 & 2694.05 \\
\hline & Unprocessed Mash PC & No & 427.47 & - & - \\
\hline
\end{tabular}

${ }^{1}$ Tyrosine Releasing Units/g of tyrosine liberated from the feed using the TU Assay = ((Sample Abs. - Blank Abs. $)$ X Standard Curve Slope $) / 60$ x $100 \mathrm{~mL} / \mathrm{Wt}$. x 10mL $/ 2 \mathrm{~mL}$

${ }^{2}$ Removal of error from tyrosine present in feed per se $=\mathrm{TU} / \mathrm{g}$ Diet Containing Protease $-\mathrm{TU} / \mathrm{g}$ Diet Containing No Protease

${ }^{3}$ Tyrosine Releasing Units/g of tyrosine liberated from the protease alone $=(\mathrm{TU} / \mathrm{g}$ Diet Containing Protease $-\mathrm{TU} / \mathrm{g}$ Diet Containing No Protease $) / \%$ Protease Inclusion 
Table 6: Effects of a Novel Protease Included in Diets that Differ in Substrate and Processing on Broiler 0-21 Day Performance

\begin{tabular}{|c|c|c|c|c|c|c|}
\hline Diet Substrate & Feed Processing & Novel Protease Inclusion & $\begin{array}{c}\text { Bird Feed Intake } \\
(\mathrm{kg})\end{array}$ & Bird Ending Weight (kg) & Bird Live Weight Gain (kg) & Feed Conversion Ratio (\%) \\
\hline \multirow{5}{*}{ All Vegetable ${ }^{1}$} & \multirow{2}{*}{ Ground Pellet ${ }^{3}$} & No & 1.027 & $0.779^{\mathrm{d}}$ & $0.732^{\mathrm{d}}$ & $1.43^{\mathrm{a}}$ \\
\hline & & Yes $^{6}$ & 1.140 & $0.878^{\mathrm{a}}$ & $0.832^{\mathrm{a}}$ & $1.34^{\text {def }}$ \\
\hline & \multirow{2}{*}{ Unprocessed Mash ${ }^{4}$} & No & 1.069 & $0.859^{\mathrm{abc}}$ & $0.813^{\text {ab }}$ & $1.32^{\mathrm{ef}}$ \\
\hline & & Yes & 1.053 & $0.816^{\text {bcd }}$ & $0.770^{\text {bcd }}$ & $1.37^{\text {bcde }}$ \\
\hline & Unprocessed Mash $\mathrm{PC}^{5}$ & No & 1.082 & $0.848^{\mathrm{abc}}$ & $0.802^{\mathrm{abc}}$ & $1.35^{\text {cdef }}$ \\
\hline \multirow{5}{*}{$\begin{array}{l}\text { Meat and Bone Meal } \\
\text { Inclusion }^{2}\end{array}$} & \multirow{2}{*}{ Ground Pellet } & No & 1.090 & $0.826^{\text {abcd }}$ & $0.780^{\text {abcd }}$ & $1.37^{\mathrm{abcd}}$ \\
\hline & & Yes & 1.079 & $0.839^{\mathrm{abc}}$ & $0.794^{\mathrm{abc}}$ & $1.33^{\text {def }}$ \\
\hline & \multirow{2}{*}{ Unprocessed Mash } & No & 1.112 & $0.821^{\text {abcd }}$ & $0.774^{\text {abcd }}$ & $1.40^{\mathrm{abc}}$ \\
\hline & & Yes & 1.064 & $0.798^{\text {cd }}$ & $0.752^{\text {cd }}$ & $1.41^{\mathrm{ab}}$ \\
\hline & Unprocessed Mash PC & No & 1.072 & $0.870^{\mathrm{ab}}$ & $0.824^{\mathrm{ab}}$ & $1.30^{\mathrm{f}}$ \\
\hline \multicolumn{7}{|c|}{ Probability Values for the Comprehensive Treatment Comparison } \\
\hline \multicolumn{3}{|c|}{ ANOVA Probability Value } & 0.3616 & 0.0343 & 0.0325 & 0.0001 \\
\hline \multicolumn{3}{|c|}{ Fisher's LSD value $^{7}$} & -- & 0.0607 & 0.0607 & 0.0553 \\
\hline \multicolumn{3}{|c|}{ Treatment $\mathrm{SEM}^{8}$} & 0.0294 & 0.0215 & 0.0215 & 0.0196 \\
\hline \multicolumn{7}{|c|}{ Diet Substrate Means } \\
\hline All Vegetable & ---- & ---- & 1.072 & 0.833 & 0.787 & 1.36 \\
\hline Meat and Bone & ---- & ---- & 1.086 & 0.821 & 0.775 & 1.38 \\
\hline \multicolumn{2}{|c|}{ Diet Substrate SEM } & & 0.0161 & 0.0133 & 0.0133 & 0.0093 \\
\hline \multicolumn{7}{|c|}{ Feed Processing Means } \\
\hline --.- & Ground Pellet & $-\overline{---}$ & 1.084 & 0.831 & 0.785 & 1.37 \\
\hline$-\cdots$ & Unprocessed Mash & ---- & 1.075 & 0.823 & 0.777 & 1.37 \\
\hline \multicolumn{2}{|c|}{ Feed Processing SEM } & & 0.0161 & 0.0133 & 0.0133 & 0.0093 \\
\hline \multicolumn{7}{|c|}{ Protease Inclusion Means } \\
\hline $\begin{array}{c}--- \\
\end{array}$ & $\begin{array}{ll}-- \\
-\cdots\end{array}$ & No & 1.074 & 0.821 & 0.775 & 1.38 \\
\hline ---- & --- & Yes & 1.084 & 0.833 & 0.787 & 1.36 \\
\hline \multicolumn{2}{|c|}{ Protease Inclusion SEM } & & 0.0161 & 0.0133 & 0.0133 & 0.0093 \\
\hline \multicolumn{7}{|c|}{ Probability Values for the Diet Substrate x Feed Processing x Protease Inclusion Factorial Treatment Arrangement } \\
\hline \multicolumn{3}{|c|}{ Diet Substrate } & 0.5427 & 0.5316 & 0.5321 & 0.1652 \\
\hline \multicolumn{3}{|c|}{ Feed Processing } & 0.6817 & 0.7005 & 0.6948 & 0.5982 \\
\hline \multicolumn{3}{|c|}{ Protease Inclusion } & 0.6657 & 0.5296 & 0.5206 & 0.2589 \\
\hline \multicolumn{3}{|c|}{ Substrate * Processing } & 0.5605 & 0.3947 & 0.3869 & 0.0008 \\
\hline \multicolumn{3}{|c|}{ Substrate * Protease } & 0.0931 & 0.3882 & 0.3853 & 0.7952 \\
\hline \multicolumn{3}{|c|}{ Processing * Protease } & 0.0732 & 0.0204 & 0.0199 & 0.0004 \\
\hline \multicolumn{3}{|c|}{ Substrate * Processing * Protease } & 0.3212 & 0.1589 & 0.1555 & 0.1070 \\
\hline \multicolumn{7}{|c|}{ Probability Values for linear contrasts on specific treatment comparisons of interest } \\
\hline \multicolumn{3}{|c|}{ Vegetable based ground pellet (protease vs. no protease) } & 0.0082 & 0.0017 & 0.0015 & 0.0019 \\
\hline \multicolumn{3}{|c|}{ Meat and Bone Inclusion based ground pellet (protease vs. no protease) } & 0.8063 & 0.6603 & 0.6574 & 0.1626 \\
\hline
\end{tabular}

${ }^{1}$ All Vegetable refers to a corn and soybean meal based diet,

${ }^{2}$ Meat and Bone Meal Inclusion refers to an $8 \%$ inclusion to a corn and soybean meal based diet

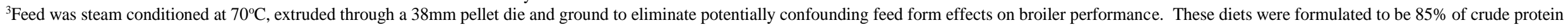

and digestible amino acid nutrient recommendations.

${ }^{4}$ Feed was not steam conditioned or pelleted. These diets were formulated to be $85 \%$ of crude protein and digestible amino acid nutrient recommendations.

${ }^{5} \mathrm{PC}$ refers to positive control diet formulations. These diets were formulated to be $100 \%$ of crude protein and digestible amino acid nutrient recommendations.

${ }^{6}$ The protease was included at $2 \%$ of the diet formulation and added at the mixer prior to pelleting when applicable.

${ }^{7}$ Fisher's least significant difference values.

${ }^{8}$ Standard error of the mean. 


\section{CIRRICULUM VITAE}

\section{Danielle A. Reese}

847 Independence Hls Vlg, Morgantown, WV 26505

Confident with the challenges associated with working under pressure. Confident with leading a group, working within a team, or as an individual.

Goals: To continue gaining knowledge in the poultry industry throughout my future career. I plan to use this knowledge to assist integrators in efficiently supplying protein to consumers.

\section{EDUCATION}

Degree obtained: Bachelor of Science in Agriculture, Animal and Nutritional Science; May 2014

Udergraduate GPA: 2.99

Expected Degree: Master of Science, Nutritional and Food Science

Expected Graduation Date: May, 2016

Current GPA: 2.73

\section{EDUCATION HONORS/AWARDS}

Graduated from Philipsburg-Osceola Area High School in 2010

\section{Grants Recieved}

- Pennsylvania Grant: 2010-2014

- $\quad$ Federal PELL Grant: 2011-2014

\section{Awards and Honors}


- Davis College of Agriculture, Natural Resources, and Design Dean's List

- Fall 2013

\title{
First Author Publications
}

\begin{abstract}
s
D.A. Reese, K.L. Foltz, and J.S. Moritz. 2015. Effect of feed mixing and sampling variables on nutrient analysis. Poult. Sci. (Accepted Abstract (101)).

D.A. Reese and J.S. Moritz. 2016. Efficacy of a novel protease provided to broiler chicks in diets that vary in composition and degree of processing. Poult. Sci. (Accepted Abstract).
\end{abstract}

\section{RESEARCH EXPERIENCE}

\section{National Meeting Paper Presentations}

- 2015 Poultry Science Association (Louisville, KY) (Graduate Student)

$>$ "Effect of feed mixing and sampling variables on nutrient analysis."

\section{Graduate Teaching Assistant}

- Teaching Assistant for Applied Nutrition II

$>$ Roles included instructing classes, grading exams, and assisting students in preparation for their research projects. I assisted in the proximate analysis, feed manufacture, chick placement, and data collection processes.

\section{Graduate Research Assistant}

- Led a study utilizing various mixing and sampling methodologies to develop a proper sampling protocol (November 2014)

- Led a study utilizing a protease enzyme product that was included in varying inclusions in diets that varied in ingredient composition and degree of processing (January 2015 - February 2016)

- Attended the National Poultry Science Association annual meeting

○ 2014- Corpus Christi, TX

○ 2015- Louisville, KY

- Led numerous WVU Animal Science Farm tours

- WVU Residence Hall (Fieldcrest Hall)

- Principles of Animal Science Class

- Charleston, $\mathrm{WV} 5^{\text {th }}$ grade class

- Dodridge County FFA chapter

- International Production and Processing Exposition, Atlanta, GA

○ 2015,2016

- Hands-on Ag Day- 2014, 2015

- North Marion High School

- Poultry Festival (Moorefield, WV) (2014) 
- Assisted with conducting an annual poultry judging competition

- Family Farm Day poultry display $(2014,2015)$

- West Virginia State FFA Poultry CDE Competition (2014)

- Created classes and coordinated the competitions

- Organic Field Day (2015)

- Prepare/serve food

- Davis College Welcome Back BBQ $(2014,2015)$

- Prepare/serve food

\section{EXPERIENCE}

Pizza Hut

2013-2014

- Server/Cook/Driver

Euro Suites

2012-2013

- Housekeeper

WVU Dining Services

2011-2013

- Food Service Worker

- Lead small groups

- Prepared food

Best Western

- Temporary/Summer Employment

- Housekeeper

K-Mart

- Temporary/College Employment

- Deli counter

SKILLS

- Feed manufacture

- Pellet durability analysis

- Diet formulation

- Cecectomy surgery

- Tibia extraction

- Ileum extraction

- Breast extraction

- Enzymatic laboratory assays

- Ether extraction using Soxhlet apparatus

- Digesta viscosity analysis 
- Poultry judging

- Proficient in Window's Microsoft Programs

- Agricultural/Animal Specific Undergraduate courses taken:

- Intro to Animal Science 150

- Principles of Animal Science 251

- Animal Nutrition 260

- Companion Animal Science 275

- Equine Management and Training 281

- Poultry Evaluation 338

Graduate Courses:

- Food Animal Diseases 493C

- Introduction to Biochemistry 410

- Statistics $511 \& 512$

- Agriculture and Natural Resources Communicants 421
- Beef Production 341

- Pork Production 353

- Applied Nutrition 1 \& 2/Lab 361\&362/363

- Poultry Production/Lab 367/369

- Dairy Heifer Management 411
- Grants and Grantsmanship 593

- Nutritional Biochemistry 512

- Food Microbiology 545 